Article

\title{
Improving Phenolic-Linked Antioxidant, Antihyperglycemic and Antibacterial Properties of Emmer and Conventional Wheat Using Beneficial Lactic Acid Bacteria
}

\author{
Ashish Christopher (D), Dipayan Sarkar and Kalidas Shetty *(D) \\ Department of Plant Sciences, North Dakota State University, Fargo, ND 58108, USA; \\ ashish.christopher@ndsu.edu (A.C.); dipayan.sarkar@ndsu.edu (D.S.) \\ * Correspondence: kalidas.shetty@ndsu.edu; Tel.: +1-701-231-5058
}

Citation: Christopher, A.; Sarkar, D.; Shetty, K. Improving Phenolic-Linked Antioxidant, Antihyperglycemic and Antibacterial Properties of Emmer and Conventional Wheat Using Beneficial Lactic Acid Bacteria. Appl. Microbiol. 2021, 1, 270-288. https:// doi.org/10.3390/applmicrobiol1020020

Academic Editor: Serena Schippa

Received: 24 June 2021

Accepted: 16 July 2021

Published: 21 July 2021

Publisher's Note: MDPI stays neutral with regard to jurisdictional claims in published maps and institutional affiliations.

Copyright: (c) 2021 by the authors. Licensee MDPI, Basel, Switzerland. This article is an open access article distributed under the terms and conditions of the Creative Commons Attribution (CC BY) license (https:// creativecommons.org/licenses/by/ $4.0 /)$.

\begin{abstract}
Beneficial lactic acid bacteria (LAB)-based fermentation is an effective bioprocessing approach to improve human-health-targeted functional benefits of plant-based food substrates, such as cereal grains. Previously, we observed high phenolic bioactive-linked antioxidant and anti-hyperglycemic properties in whole grain Emmer (hulled). In this study, beneficial LAB (Lactiplantibacillus plantarum) was recruited to ferment $(0-72 \mathrm{~h})$ aqueous extracts $(0.4 \mathrm{~g} / \mathrm{mL}$ concentration) of previously optimized hulled Emmer wheat and conventional red spring wheat $\mathrm{cv}$. Barlow. The fermented and unfermented (control) wheat extracts were analyzed for phenolic content, phenolic profile, antioxidant activity, and antihyperglycemic properties ( $\alpha$-amylase and $\alpha$-glucosidase enzyme inhibitory activity) using in vitro assay models. Additionally, antimicrobial activity against pathogenic bacteria Helicobacter pylori, and potential prebiotic activity supporting the growth of beneficial Bifidobacterium longum were also investigated. Improvement in antioxidant activity and antihyperglycemic functional benefits were observed, while soluble phenolic content remained high after $72 \mathrm{~h}$ fermentation. Antimicrobial activity against $H$. pylori was also observed in 48 and $72 \mathrm{~h}$ fermented wheat extracts. This study provides an insight into the efficacy of LAB-based fermentation as a safe bioprocessing tool to design health-targeted functional foods and ingredients from underutilized whole grains like Emmer for targeting type 2 diabetes dietary benefits.
\end{abstract}

Keywords: ancient wheat; antimicrobial; antioxidant; antihyperglycemic; lactic acid bacteria; fermentation; phenolics

\section{Introduction}

The fermentation of cereal grains with beneficial lactic acid bacteria (LAB) is a useful bioprocessing approach to enhance nutritional, organoleptic, and bioactive properties, which has wider relevance in health-targeted food applications. There are many dietary advantages associated with the LAB-based fermentation of whole and processed grains, such as (i) the enhanced mobilization and solubilization of health-relevant bioactive nutrients, (ii) the improvement in the stability of the functional properties of bioactive compounds, (iii) the addition of potential prebiotic and probiotic functions, (iv) the food-safety benefits associated with the improved antimicrobial property, and (v) the removal of undesirable toxins or antinutrients [1,2]. Such improvements with LAB fermentation have dual functional benefits for enhancing post-harvest preservation or shelf-life and for the improvement of human-health-targeted nutritional qualities of cereal-grain-based food substrates [3].

Globally, there is a renewed interest in the fermentation-based bioprocessing of cereal grains, which is mostly driven by an increasing consumer awareness of the potential health benefits of fermented foods and beverages. Additionally, cereal grains that are rich in human-health-protective bioactive compounds, dietary fibers, and minerals are also good substrate sources for supporting the growth and viability of beneficial bacteria, such as 
LAB. Therefore, targeting a LAB-based fermentation strategy to enhance the human-healthrelevant bioactive and nutritional qualities of cereal-grain-based functional foods and ingredients and concurrently improving their keeping qualities have significant merit. These cereal-grain-based fermented foods with enhanced nutritional profile and bioactive functionality have wider relevance for their value-added integration in dietary support strategies to help address an increasing prevalence of diet- and lifestyle-influenced chronic diseases, such as type 2 diabetes, cardiovascular diseases, obesity, and dyslipidemia.

Among different cereal grains, whole wheat is an excellent substrate source that supports the growth of single or mixed bacterial starter cultures, including bacterial combined cultures as well as probiotic cultures containing beneficial human gut microbes such as LAB [4-9]. The fermentation of wheat with LAB potentially enhances its bioactive functionality due to beneficial changes in the nutritional, rheological, and organoleptic properties of the acidified dough matrix, along with an improvement in the shelf-life of wheat-based fermented foods [10-17]. Emmer, an ancient and underutilized wheat, has a good nutritional and bioactive profile, thereby making it an attractive choice as a source for functional food and dietary ingredients with human-health-relevant benefits [18-26]. Previously, we reported high phenolic bioactive-linked antioxidant and antihyperglycemic functionalities in aqueous extracts of hulled Emmer wheat with its potential relevance as a dietary target against type 2 diabetes [21]. Additionally, another study found that the fermentation of Emmer flour, gelatinized Emmer flour, and Emmer malt with Lactobacillus, Weissella and Pediococcus spp. improved the physical, chemical, nutritional, and sensory properties with the aim of developing commercial Emmer-based fermented beverages with probiotic functions [27]. These studies suggest that Emmer wheat is a promising substrate source for designing LAB-based fermented foods and beverages with diverse human-health-targeted functional benefits.

Therefore, the aim of this current study was to recruit Lactiplantibacillus plantarum (previously known as Lactobacillus plantarum), a widely distributed LAB in the plant-based food matrix, to ferment previously optimized [21] aqueous extracts of hulled North Dakota common Emmer and modern-day hard red spring wheat cv. Barlow to improve the antioxidant, antihyperglycemic, and antimicrobial properties. The potential efficacy of LAB fermentation to modulate the total soluble phenolic content (TSP), phenolic profile, antioxidant activity, glycemic control via $\alpha$-amylase and $\alpha$-glucosidase enzyme inhibitory activities, antimicrobial activity against Helicobacter pylori, and prebiotic property supporting the growth of beneficial Bifidobacterium longum were determined using rapid in vitro assay models. The wider goal was to provide insights on how such a bioprocessing approach involving LAB-based fermentation strategy can positively influence the healthtargeted bioactive-linked functional properties such as the composition of health-relevant phenolic compounds and the associated antioxidant, antihyperglycemic, antimicrobial, and prebiotic properties, which can be subsequently integrated into dietary support strategies targeting wider health benefits.

\section{Materials and Methods}

\subsection{Preparation of Wheat Extracts}

In this study, the previously screened wheat varieties [21], hulled North Dakota Common Emmer and hard red spring wheat cv. Barlow, were obtained from Kaul Organic Farms (Harvey, ND-58341, USA) and from the North Dakota Research Experiment Station (North Dakota State University Wheat Breeding Program, Fargo, ND-58108) respectively. The year of harvest for these wheat varieties was 2017. Using a WonderMill (WonderMill, Pocatello, ID, USA), the wheat grains (Emmer with hull and Barlow without hull) were milled at the pastry setting to obtain a fine flour. Extraction was done in duplicate using the cold-water extraction procedure as described earlier [21]. For this study, $20 \mathrm{~g}$ of the wheat flour was blended in $50 \mathrm{~mL}$ distilled cold water in a Warring Blender at low speed for $5 \mathrm{~min}$. The concentration of the Emmer and Barlow wheat extracts was $0.4 \mathrm{~g} / \mathrm{mL}$. The extracts were centrifuged at $8500 \mathrm{rpm}$ for $20 \mathrm{~min}$, and the supernatant was collected 
and re-centrifuged at $8500 \mathrm{rpm}$ for $15 \mathrm{~min}$, and the extracts were stored at $4{ }^{\circ} \mathrm{C}$. Prior to fermentation, the wheat extracts were pasteurized in a water bath at $70^{\circ} \mathrm{C}$ for $20 \mathrm{~min}$, after which the pasteurized extracts were immersed in an ice bath to ensure rapid cool-down to room temperature.

\subsection{Bacterial Strains Used}

The bacterial strains used in this study were Lactiplantibacillus plantarum (ATCC 8014), Bifidobacterium longum (ATCC 15708), and Helicobacter pylori (ATCC 43579). The LAB and H. pylori cultures were stored as frozen stocks in their respective MRS (Difco), and H. pylori special peptone (HPSP) broths, with both media containing $20 \%$ glycerol as the cryoprotectant. The revival and growth of the bacterial stocks was done according to a protocol described earlier [28]. For the HPSP broth, $10 \mathrm{~g} \mathrm{~L}^{-1}$ of special peptone (Oxoid, Basingstoke, UK), $5 \mathrm{~g} \mathrm{~L}^{-1}$ of sodium chloride (Fisher Scientific, Waltham, MA, USA), $5 \mathrm{~g} \mathrm{~L}^{-1}$ of yeast extract (Difco), and $5 \mathrm{~g} \mathrm{~L}^{-1}$ of beef extract (Difco) were dissolved in distilled water and autoclaved. The MRS broth was prepared according to the manufacturer's specifications and autoclaved. The MRS and HPSP agar plates were prepared by the addition of $15 \mathrm{~g} \mathrm{~L}^{-1}$ of granulated agar (Difco) to the respective broths, followed by autoclaving. For revival of the frozen bacterial stocks, $100 \mu \mathrm{L}$ of thawed LAB and H. pylori stocks were inoculated in $10 \mathrm{~mL}$ sterile MRS or HPSP broth and incubated at $37^{\circ} \mathrm{C}$ for $24 \mathrm{~h}$, after which $100 \mu \mathrm{L}$ of the $24 \mathrm{~h}$ culture was re-inoculated into $10 \mathrm{~mL}$ of sterile MRS or HPSP broth and incubated at $37{ }^{\circ} \mathrm{C}$ for another $24 \mathrm{~h}$. The cultures were then used in the respective fermentation, antimicrobial, and prebiotic assays.

\subsection{Wheat Fermentation}

Fermentation was done based on a protocol described earlier [29], in which $10 \mathrm{~mL}$ of the revived L. plantarum culture was added to $90 \mathrm{~mL}$ of pasteurized wheat extracts in sterile $125 \mathrm{~mL}$ flasks. For the control or unfermented extracts, $10 \mathrm{~mL}$ of sterile MRS broth was added. The extracts were then incubated in duplicate at $37{ }^{\circ} \mathrm{C}$ for a period of $72 \mathrm{~h}$, and samples were collected at the $0,24,48$, and $72 \mathrm{~h}$ time points of fermentation for in vitro analysis. The growth of L. plantarum was measured at each time point by serially diluting the fermented extracts, followed by plating onto MRS agar plates. The plates were incubated anaerobically at $37{ }^{\circ} \mathrm{C}$ for $48 \mathrm{~h}$ in BBL GasPak jars (Becton, Dickinson \& Co., Sparks Glencoe, MD, USA) containing the BD GasPak EZ anaerobe container system sachets (Becton, Dickinson \& Co), and the number of colonies was expressed in $\log$ CFU / mL. The samples collected at each time point were centrifuged at $8500 \mathrm{rpm}$ for $15 \mathrm{~min}$, after which the supernatant was collected, and the $\mathrm{pH}$ of one the duplicates of the fermented extract was adjusted using $1 \mathrm{M} \mathrm{NaOH}$ to match its control (unfermented extract, $\mathrm{pH}$ 6.3-6.6), while an equal amount of distilled water was added to the duplicate of the fermented extract to maintain natural acidic $\mathrm{pH}$ (without adjustment). The unfermented and fermented extracts (with and without $\mathrm{pH}$ adjustment) were analyzed for their TSP content, antioxidant activity, and enzyme inhibitory activity against $\alpha$-amylase and $\alpha$-glucosidase at the $0,24,48$, and $72 \mathrm{~h}$ time points of the fermentation period. Also, samples of the unfermented and fermented extracts (with and without $\mathrm{pH}$ adjustment) at each time point was filtered through sterile $0.22 \mu \mathrm{m}$ syringe filters (Millipore Corp, Burlington, MA, USA) and stored at $-20^{\circ} \mathrm{C}$ for later analysis of phenolic compounds, antimicrobial activity, and prebiotic function.

\subsection{Total Soluble Phenolic Content}

The soluble phenolic content of the unfermented and fermented wheat extracts $(0.4 \mathrm{~g} / \mathrm{mL})$ was determined using the Folin-Ciocalteu method based on a protocol described previously [30]. For this assay, $0.5 \mathrm{~mL}$ aliquots of the unfermented and fermented wheat extracts were taken into respective glass tubes, after which $1 \mathrm{~mL}$ of $95 \%$ ethanol, $0.5 \mathrm{~mL}$ of $50 \%(v / v)$ Folin-Ciocalteu reagent, and $1 \mathrm{~mL}$ of $5 \%$ sodium carbonate were added sequentially. The tubes were mixed by a vortex machine and incubated for 60 min under dark 
conditions. The absorbance values were measured at $725 \mathrm{~nm}$ with a UV-visible spectrophotometer (Genesys 10S UV-VIS spectrophotometer, Thermo Scientific, New York, NY, USA). Using a standard curve of different concentrations of gallic acid in 95\% ethanol, the absorbance values of the extracts were converted and expressed as TSP content in milligrams of gallic acid equivalents per gram of dry weight (mg GAE/g DW).

\subsection{Phenolic Compound Characterization (High-Performance Liquid Chromatography Assay)}

The profile of the phenolic compounds was determined using a high-performance liquid chromatography (HPLC) assay method, in which $5 \mu \mathrm{L}$ of the unfermented and fermented wheat extracts was injected using an Agilent ALS 1200 auto-extractor into an Agilent 1260 series (Agilent Technologies, Palo Alto, Santa Clara, CA, USA) HPLC equipped with a D1100 CE diode array detector. The solvents used for gradient elution were $10 \mathrm{mM}$ phosphoric acid ( $\mathrm{pH} 2.5$ ) and 100\% methanol. The methanol concentration was increased to $60 \%$ for the first $8 \mathrm{~min}$, then to $100 \%$ over the next $7 \mathrm{~min}$, then decreased to $0 \%$ for the next $3 \mathrm{~min}$ and was maintained for $7 \mathrm{~min}$ with a total run time of $25 \mathrm{~min}$ per injected sample run. The analytical column used was Agilent Zorbax SB-C18, 250-4.6 mm i.d., with packing material of $5 \mu \mathrm{m}$ particle size at a flow rate of $0.7 \mathrm{~mL} / \mathrm{min}$ at room temperature. The absorbance values were recorded at $214 \mathrm{~nm}, 230 \mathrm{~nm}, 260 \mathrm{~nm}$, and $306 \mathrm{~nm}$, and the chromatogram was integrated using Agilent Chem station enhanced integrator. Pure standards of benzoic acid, gallic acid, protocatechuic acid, ferulic acid, and catechin in $100 \%$ methanol were used to calibrate the respective standard curves and retention times. The phenolic compounds detected in the extracts were expressed in microgram per gram of dry weight $(\mu \mathrm{g} / \mathrm{g} D W)$. Chromatograms of detected phenolic compounds of fermented and unfermented wheat extracts are included in the result and discussion section.

\subsection{Antioxidant Activity Assay}

The antioxidant activity of the unfermented and fermented wheat extracts was measured by their scavenging activity against the free radicals 2, 2-dipheny-1-picryl hydrazyl (DPPH) (D9132-5G, Sigma-Aldrich, St. Louis, MO, USA), and 2, 2-azino-bis(3-ethylbenzthiazoline-6-sulfonic acid) (ABTS) (A1888-5G, Sigma-Aldrich) respectively. The DPPH scavenging assay was based on a protocol described earlier [31], in which $0.25 \mathrm{~mL}$ of the wheat extracts was added to $1.25 \mathrm{~mL}$ of $60 \mathrm{mM}$ DPPH prepared in $95 \%$ ethanol, while the controls had $0.25 \mathrm{~mL}$ of $95 \%$ ethanol instead of the sample extract. After 5 min of incubation, the extracts and their corresponding controls were centrifuged at $13,000 \mathrm{rpm}$ for $1 \mathrm{~min}$. and the absorbance values of the supernatants was measured at 517nm using a UV-visible spectrophotometer (Genesys 10S UV-VIS spectrophotometer, Thermo Scientific, NY). The ABTS scavenging assay was based on a protocol described earlier [32], in which $0.05 \mathrm{~mL}$ of the wheat extracts was added to $1 \mathrm{~mL}$ of ABTS prepared in $95 \%$ ethanol, while the controls had $0.05 \mathrm{~mL}$ of $95 \%$ ethanol in $1 \mathrm{~mL}$ ABTS. After $2 \mathrm{~min}$ of incubation, the extracts and their controls were centrifuged at 13,000 rpm for $1 \mathrm{~min}$, and the absorbance values of the supernatant was measured at $734 \mathrm{~nm}$ with a UV-visible spectrophotometer (Genesys 10S UV-VIS spectrophotometer, Thermo Scientific, NY). For the ABTS and DPPH assays, Trolox was prepared in 95\% ethanol and serially diluted to give different concentrations $(10,5,2.5,1.25,0.625$, and $0.3125 \mathrm{mg} / \mathrm{mL})$, which was used as the positive control. The absorbance values from the DPPH and ABTS radical scavenging assays were used to calculate the percentage of antioxidant activity for each extract using the following formula:

$$
\% \text { Antioxidant activity }=\frac{\text { Control }^{\text {absorbance }}-\text { Extract }^{\text {absorbance }}}{\text { Control }^{\text {absorbance }}} \times 100
$$

\section{7. $\alpha$-Amylase Enzyme Inhibitory Activity}

The $\alpha$-amylase enzyme inhibitory activity of the unfermented and fermented wheat extracts was measured based on a protocol described earlier [31], and the activity was 
measured in a dose-dependent manner using undiluted, half, and one-fifth diluted sample extracts. The sample extracts were diluted using distilled water, and $500 \mu \mathrm{L}$ of undiluted and diluted extracts were added to respective $1 \mathrm{~mL}$ glass tubes, while the control tubes had $500 \mu \mathrm{L}$ of $0.1 \mathrm{M}$ sodium phosphate buffer (containing $0.006 \mathrm{M}$ sodium chloride at $\mathrm{pH}$ 6.9). Each extract had a corresponding sample blank tube containing only $500 \mu \mathrm{L}$ of the sample extract and buffer instead of the enzyme. Then $500 \mu \mathrm{L}$ of porcine pancreatic $\alpha$-amylase (0.5 mg/mL buffer) (EC 3.2.1.1, purchased from Sigma Chemical Co, St Louis, MO, USA) was added only to the sample and control tubes and incubated for $10 \mathrm{~min}$ at $25^{\circ} \mathrm{C}$. After incubation, $500 \mu \mathrm{L}$ of the substrate (1\% starch in buffer) was added to all of the tubes and incubated again for $10 \mathrm{~min}$ at $25^{\circ} \mathrm{C}$. Then $1 \mathrm{~mL}$ of 3,5 dinitro salicylic acid was added, and the tubes were incubated in a boiling water bath for $10 \mathrm{~min}$ to stop the reaction. After removing the tubes from the water bath and cooling them down to room temperature, $10 \mathrm{~mL}$ of distilled water was added to all the tubes to ensure that the absorbance values in the control tubes ranged between 1.0 and 1.2, and the absorbance of all the tubes was measured at $540 \mathrm{~nm}$ using a UV-visible spectrophotometer (Genesys 10S UV-VIS spectrophotometer, Thermo Scientific, NY). A positive control with acarbose was prepared in distilled water and serially diluted to give different concentrations $(10,5,2.5,1.25,0.625$, and $0.3125 \mathrm{mg} / \mathrm{mL}$ ), which was included in the study for comparison. The absorbance values were then used to calculate the percentage of enzyme inhibitory activity of the fermented and unfermented sample extracts using the following formula:

$\%$ Inhibition $=\frac{\text { Control }^{\text {absorbance }}-\left(\text { Extract }^{\text {absorbance }}-\text { Extract blanc }^{\text {absorbance }}\right)}{\text { Control }^{\text {absorbance }}} \times 100$

\section{8. $\alpha$-Glucosidase Enzyme Enhibitory Activity}

The $\alpha$-glucosidase enzyme inhibitory activity of the unfermented and fermented wheat extracts was measured based on a protocol described earlier [31]. The enzyme inhibitory activity was measured in a dose-dependent manner at undiluted, half, and one-fifth dilutions of the sample extracts. The extracts were diluted with $0.1 \mathrm{M}$ potassium phosphate buffer ( $\mathrm{pH}$ 6.9) in 96-well micro titer plates in which $50 \mu \mathrm{L}, 25 \mu \mathrm{L}$, and $10 \mu \mathrm{L}$ of each extract was pipetted, and the final volume was increased to $50 \mu \mathrm{L}$ by the addition of potassium phosphate buffer. Each extract had a corresponding control of $50 \mu \mathrm{L}$ (buffer instead of sample), and the volume in all the wells was made to up to a final volume of $100 \mu \mathrm{L}$ by the addition of $50 \mu \mathrm{L}$ of buffer. Then $100 \mu \mathrm{L}$ of buffer containing yeast $\alpha$-glucosidase enzyme (1 U/mL) (EC 3.2.1.20, purchased from Sigma Chemical Co, St. Louis, MO, USA) was added to each well and incubated for $10 \mathrm{~min}$ at $25^{\circ} \mathrm{C}$, after which $50 \mu \mathrm{L}$ of the substrate and $5 \mathrm{mM}$ p-nitrophenyl- $\alpha$-D- glucopyranoside solution (prepared in buffer) was added to each well, followed by $5 \mathrm{~min}$ of incubation at $25^{\circ} \mathrm{C}$. A positive control with acarbose was prepared in distilled water and serially diluted to give different concentrations $(10,5,2.5,1.25,0.625$, and $0.3125 \mathrm{mg} / \mathrm{mL})$, which were included in the study for comparison. The absorbance of all of the wells was measured at $405 \mathrm{~nm}$ using a microplate reader (Thermomax, Molecular Devices, San Jose, CA, USA) at the 0 and 5 min time point of the $5 \mathrm{~min}$ incubation period, and the absorbance values were used to calculate the percentage of enzyme inhibitory activity using the following formula:

$$
\% \text { Inhibition }=\frac{\left(\text { Control }^{\text {abs }} 5 \mathrm{~min}-\text { Control }^{\text {abs }} 0 \mathrm{~min}\right)-\left(\text { Extract }^{\text {abs }} 5 \mathrm{~min}-\text { Extract }^{\mathrm{abs}} 0 \mathrm{~min}\right)}{\text { Control } \left.^{\mathrm{abs}} 5 \mathrm{~min}-\text { Control }^{\mathrm{abs}} 0 \mathrm{~min}\right)} \times 100
$$

\subsection{Antimicrobial Activity}

The antimicrobial activity of the unfermented and fermented wheat extracts against Helicobacter pylori was measured using the agar diffusion method [28]. Frozen $H$. pylori culture was revived and streaked onto HPSP agar plates with the help of sterile cotton swabs. Then sterile $12.7 \mathrm{~mm}$ paper discs (BBL Taxo, Becton, Dickinson \& Co, Sparks, MD, USA) were placed on the HPSP agar plates, and $100 \mu \mathrm{L}$ of the filter-sterilized wheat extracts from 
the $0,24,48$, and 72-h time points were added to their respective paper discs with each plate having a control disc of sterile water. The plates were incubated at $37^{\circ} \mathrm{C}$ for $48 \mathrm{~h}$ in BBL GasPak jars (Becton, Dickinson \& Co) containing BD GasPak Campy container system sachets (Becton, Dickinson \& Co, Sparks, MD, USA) to help maintain a microaerophilic environment. After incubation, the plates were examined for any zones of inhibition (no growth) around the discs, and the diameter of the zones of inhibition was measured in millimeters.

\subsection{Prebiotic Activity}

The potential prebiotic activity of the unfermented and fermented wheat extracts was measured using the LAB proliferation prebiotic assay to determine the growth of Bifidobacterium longum [28]. Frozen B. longum culture was revived and diluted 100-fold by the addition of $100 \mu \mathrm{L}$ of culture to $9.9 \mathrm{~mL}$ sterile water. This diluted culture was used as the inoculum for the LAB proliferation assay, in which $1 \mathrm{~mL}$ of the filter-sterilized extracts were added to their respective tubes containing $9 \mathrm{~mL}$ sterile MRS broth, while the control tube had $1 \mathrm{~mL}$ of sterile water instead of the extract. This was followed by the inoculation of $100 \mu \mathrm{L}$ of the diluted $B$. longum culture to each tube, and the tubes were incubated for $48 \mathrm{~h}$, during which time the growth of B. longum was measured at the $0,6,12,24$, and $48 \mathrm{~h}$ time points. At each assay time point, $100 \mu \mathrm{L}$ of the unfermented and fermented extracts containing B. longum were serially diluted in sterile water, and the dilutions plated onto MRS agar plates followed by incubation at $37{ }^{\circ} \mathrm{C}$ for $48 \mathrm{~h}$ in anaerobic BBL GasPak jars (Becton, Dickinson \& Co., Sparks, MD, USA) containing BD GasPak EZ anaerobe container system sachets with indicator (Becton, Dickinson \& Co) to help maintain an anaerobic environment. The number of colonies in the control and extract plates were counted and expressed as $\log \mathrm{CFU} / \mathrm{mL}$.

\subsection{Statistical Analysis}

Wheat fermentation, characterization of phenolic compounds and all in vitro assays were repeated twice with repeat extractions and duplicate samples. The mean and standard error were calculated from 12 (n) data points using Microsoft Excel XP software. The analysis of covariance was determined using Statistical Analysis Software (SAS version 9.4, SAS Institute, Cary, NC, USA). Statistical mean separation between sample extracts, fermentation time points, and sample extract $\times$ fermentation time point interactions were determined using Tukey's test at a 0.05 probability level. Statistically significant differences between sample extract $\times$ fermentation time point interactions are presented in the figures and tables. For ABTS-based antioxidant activity results, statistically significant differences between fermentation time points are presented, as sample extract $\times$ fermentation time point interactions had no significant effect on this parameter.

\section{Results and Discussion}

\subsection{Total Soluble Phenolic Content and Phenolic Profile}

The nutritional and other bioactive-associated health benefits of plant-based fermented foods and beverages largely depends on their ability to retain and stabilize protective functional bioactive compounds like phenolics beyond the basic macronutrient profiles. The increasing demand for plant-based fermented foods and beverages is partly based on the wider perception of consumers about the potential bioactive enrichment and associated improvement of wider health-relevant nutritional and functional benefits. In general, the physio-chemical properties of a fermented food matrix change substantially during fermentation, which influences the composition and functional bioactivity of phenolic compounds present in plant-based food substrates. Therefore, to develop health-targeted fermented foods and beverages, it is important to understand the impact of fermentation on the composition and content of phenolic bioactives and their health-protective functional benefits, such as antioxidant, antihyperglycemic, antimicrobial, and prebiotic properties. 
In this study, the TSP content of fermented and unfermented wheat extracts $(0.4 \mathrm{~g} / \mathrm{mL})$ ranged between 0.61 to $0.76 \mathrm{mg}$ GAE/g DW (Figure 1).

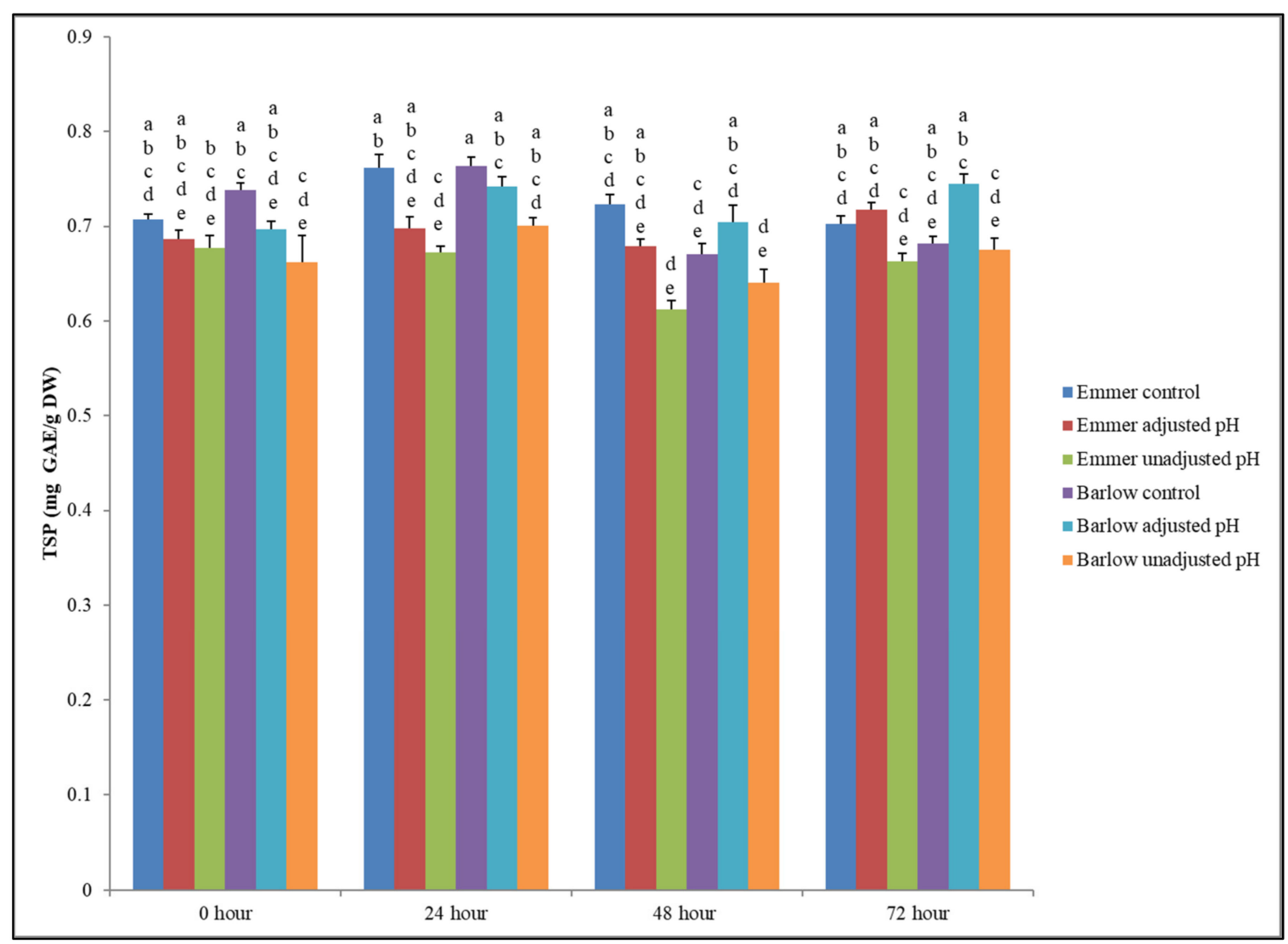

Figure 1. Total soluble phenolic (TSP) content (mg GAE/g DW) of unfermented (control) and fermented (adjusted pH and unadjusted $\mathrm{pH}$ ) Emmer and Barlow wheat extracts $(0.4 \mathrm{~g} / \mathrm{mL})$ at 0, 24, 48, and $72 \mathrm{~h}$ fermentation time points. Data is expressed as the mean \pm standard error. Different letters indicate statistically significant differences in TSP content between sample extract $\times$ fermentation time point interactions $(p<0.05)$.

Statistically significant differences in TSP content were observed between sample extracts, fermentation time points, and sample extract $\times$ fermentation time point interactions $(p<0.05)$ (statistically significant effect of 2-way interaction on TSP content is presented in Figure 1). During the initial fermentation stages (0-24 h), a higher TSP content was observed in unfermented wheat extracts (control) (Figure 1). However, after $72 \mathrm{~h}$ of fermentation, fermented wheat extracts (Emmer and Barlow) with adjusted $\mathrm{pH}$ had higher TSP content but were statistically at par with the respective controls. In this study, the mean TSP content was comparatively lower among the fermented extracts with acidic $\mathrm{pH}$ (without adjustment), which could be due to the effect of acidic condition on the activity of Folin-Ciocalteu, which is a reducing reagent that requires an alkaline $\mathrm{pH}$ to fully bind to the phenolic compounds present in the extracts. Furthermore, the stability of phenolic compounds depends on the structure of the compound and $\mathrm{pH}$ of the environment, and a $\mathrm{pH}$ close to neutral favors a better stability of the water-soluble phenolics [33]. The TSP content of the unfermented Emmer and Barlow extracts in this study was slightly lower when compared to the results of our previous study [21]. The differences in the TSP content between these two studies was due to the differences in the year of harvest, as environmental factors of each specific crop year can have a significant impact on the stress-protective phenolic content and profile [34-36]. In this current study, the year of harvest for Emmer and Barlow was 2017, while in the previous study the crop years were 2015 and 2016 [21]. Overall, higher retention of soluble phenolic content was observed in all fermented wheat extracts (with adjusted $\mathrm{pH}$ ) even after $72 \mathrm{~h}$ fermentation. 
The results also indicate that L. plantarum-based fermentation had no detrimental impact on soluble phenolic content of Emmer and Barlow aqueous extracts, and therefore fermentation, as a bioprocessing approach, can be recruited to develop phenolic bioactiverich functional foods and ingredients from these targeted wheat substrates. In addition to the TSP content, it is important to know that the composition of soluble, bioavailable phenolic compounds in fermented food matrices and their potential structure-function changes during fermentation for better defining phenolic-linked functional benefits.

A high-performance liquid chromatography (HPLC)-based analytical technique was used to detect and quantify major phenolic compounds present in the aqueous extracts of fermented and unfermented wheat. The phenolic compounds detected in this study were benzoic acid, gallic acid, protocatechuic acid (hydroxybenzoic acid group), ferulic acid (hydroxycinnamic acid group), and catechin (flavan-3-ol) (Table 1) (A chromatogram of individual phenolic compounds is presented in Figure 2).

Table 1. Profile and content ( $\mu \mathrm{g} / \mathrm{g}$ DW) of individual phenolic compound determined using high-performance liquid chromatography (HPLC).

\begin{tabular}{|c|c|c|c|c|c|c|c|}
\hline $\begin{array}{c}\text { Time Point } \\
\text { (Hours) }\end{array}$ & $\begin{array}{l}\text { Sample } \\
\text { Extract }^{\text {a }}\end{array}$ & & Benzoic Acid & Catechin & Gallic Acid & Protocatechuic Acid & Ferulic Acid \\
\hline \multirow[t]{6}{*}{0} & Emmer & Unfermented & $0.88 \pm 0.0$ fghij & $9.95 \pm 0.0 \mathrm{~cd}$ & $11.50 \pm 0.0 \mathrm{abcdef}$ & $0.31 \pm 0.0 \mathrm{hij}$ & $1.17 \pm 0.0 \mathrm{ef}$ \\
\hline & & Fermented/adjusted pH & $0.93 \pm 0.0 \mathrm{defg}$ & $9.68 \pm 0.2 \mathrm{~d}$ & $10.79 \pm 0.0 \mathrm{bcdef}$ & $0.28 \pm 0.0 \mathrm{ijk}$ & $1.10 \pm 0.1 \mathrm{f}$ \\
\hline & & Fermented/unadjusted $\mathrm{pH}$ & $1.03 \pm 0.0 \mathrm{abc}$ & $9.94 \pm 0.3 \mathrm{~cd}$ & $10.99 \pm 0.1 \mathrm{abcdef}$ & $0.33 \pm 0.0 \mathrm{ghij}$ & $1.39 \pm 0.0 \mathrm{~d}$ \\
\hline & Barlow & Unfermented & $0.93 \pm 0.0$ defg & $8.65 \pm 0.4 \mathrm{ef}$ & $12.33 \pm 0.0 \mathrm{abcd}$ & $0.52 \pm 0.0 \mathrm{ab}$ & $2.20 \pm 0.0 \mathrm{a}$ \\
\hline & & Fermented/adjusted pH & $0.96 \pm 0.0 \mathrm{cdef}$ & $7.94 \pm 0.0 \mathrm{~g}$ & $11.91 \pm 0.0$ abcde & $0.48 \pm 0.0$ abcde & $1.60 \pm 0.0 \mathrm{c}$ \\
\hline & & Fermented/unadjusted $\mathrm{pH}$ & $1.07 \pm 0.0 \mathrm{a}$ & $8.73 \pm 0.1 \mathrm{e}$ & $12.35 \pm 0.0 \mathrm{abcd}$ & $0.52 \pm 0.0 \mathrm{abc}$ & $2.17 \pm 0.0 \mathrm{a}$ \\
\hline \multirow[t]{3}{*}{24} & Emmer & Unfermented & $0.91 \pm 0.0 \mathrm{efg}$ & $10.35 \pm 0.0 \mathrm{bc}$ & $13.0 \pm 0.0 \mathrm{a}$ & $0.37 \pm 0.0$ fghi & $1.12 \pm 0.0 \mathrm{f}$ \\
\hline & & Fermented/adjusted pH & $0.92 \pm 0.0$ defg & $0.35 \pm 0.1 \mathrm{~h}$ & $9.53 \pm 0.0 f$ & $0.26 \pm 0.0 \mathrm{jk}$ & ND \\
\hline & & Fermented/unadjusted $\mathrm{pH}$ & $1.06 \pm 0.0 \mathrm{ab}$ & $0.40 \pm 0.0 \mathrm{~h}$ & $7.29 \pm 0.0 \mathrm{~g}$ & $0.20 \pm 0.0 \mathrm{kl}$ & ND \\
\hline $\begin{array}{l}\text { Time Point } \\
\text { (Hours) }\end{array}$ & $\begin{array}{l}\text { Sample } \\
\text { Extract }^{\text {a }}\end{array}$ & & Benzoic Acid & Catechin & Gallic Acid & Protocatechuic Acid & Ferulic Acid \\
\hline \multirow{9}{*}{48} & Barlow & Unfermented & $0.86 \pm 0.0 \mathrm{ghij}$ & $8.15 \pm 0.0 \mathrm{fg}$ & $12.73 \pm 0.0 \mathrm{ab}$ & $0.57 \pm 0.0 \mathrm{a}$ & $1.93 \pm 0.0 \mathrm{~b}$ \\
\hline & & Fermented/adjusted pH & $0.92 \pm 0.0 \mathrm{defg}$ & $0.29 \pm 0.0 \mathrm{~h}$ & $11.41 \pm 0.0$ abcdef & $0.37 \pm 0.0$ fghi & ND \\
\hline & & Fermented/unadjusted $\mathrm{pH}$ & $0.99 \pm 0.0 \mathrm{abcd}$ & $0.44 \pm 0.0 \mathrm{~h}$ & $10.11 \pm 0.0 \mathrm{ef}$ & $0.14 \pm 0.01$ & ND \\
\hline & Emmer & Unfermented & $0.79 \pm 0.0 \mathrm{jk}$ & $10.82 \pm 0.0 \mathrm{ab}$ & $12.84 \pm 0.5 \mathrm{a}$ & $0.38 \pm 0.0$ efghi & $0.97 \pm 0.0 \mathrm{~g}$ \\
\hline & & Fermented/adjusted pH & $0.90 \pm 0.0$ efgh & $0.06 \pm 0.0 \mathrm{~h}$ & $10.10 \pm 0.6 \mathrm{ef}$ & $0.33 \pm 0.0 \mathrm{ghij}$ & ND \\
\hline & & Fermented/unadjusted $\mathrm{pH}$ & $0.98 \pm 0.0$ bcde & $0.34 \pm 0.0 \mathrm{~h}$ & $12.48 \pm 0.3 \mathrm{abc}$ & $0.41 \pm 0.0$ defgh & ND \\
\hline & Barlow & Unfermented & $0.81 \pm 0.0 \mathrm{ijk}$ & $7.89 \pm 0.0 \mathrm{~g}$ & $12.27 \pm 0.0 \mathrm{abcd}$ & $0.56 \pm 0.0 \mathrm{a}$ & $1.21 \pm 0.0 \mathrm{e}$ \\
\hline & & Fermented/adjusted pH & $0.87 \pm 0.0$ ghij & $0.10 \pm 0.0 \mathrm{~h}$ & $10.48 \pm 0.0$ cdef & $0.43 \pm 0.0 \mathrm{bcdef}$ & ND \\
\hline & & Fermented/unadjusted $\mathrm{pH}$ & $0.89 \pm 0.0$ fghi & $0.13 \pm 0.0 \mathrm{~h}$ & $11.16 \pm 0.1 \mathrm{abcdef}$ & $0.49 \pm 0.1 \mathrm{abcd}$ & ND \\
\hline $\begin{array}{l}\text { Time Point } \\
\text { (Hours) }\end{array}$ & $\begin{array}{l}\text { Sample } \\
\text { Extract }^{\text {a }}\end{array}$ & & Benzoic Acid & Catechin & Gallic Acid & Protocatechuic Acid & Ferulic Acid \\
\hline \multirow[t]{6}{*}{72} & Emmer & Unfermented & $0.74 \pm 0.0 \mathrm{k}$ & $10.94 \pm 0.0 \mathrm{a}$ & $12.62 \pm 0.0 \mathrm{ab}$ & $0.37 \pm 0.0$ fghi & $0.66 \pm 0.0 \mathrm{~h}$ \\
\hline & & Fermented/adjusted pH & $0.92 \pm 0.0 \mathrm{defg}$ & $0.08 \pm 0.0 \mathrm{~h}$ & $9.79 \pm 0.5 \mathrm{f}$ & $0.37 \pm 0.0$ fghi & ND \\
\hline & & Fermented/unadjusted $\mathrm{pH}$ & $0.94 \pm 0.1$ defg & $0.33 \pm 0.0 \mathrm{~h}$ & $10.34 \pm 1.5 \mathrm{def}$ & $0.42 \pm 0.0$ cdefg & ND \\
\hline & Barlow & Unfermented & $0.82 \pm 0.0 \mathrm{hijk}$ & $8.36 \pm 0.0 \mathrm{efg}$ & $12.47 \pm 0.0 \mathrm{abc}$ & $0.56 \pm 0.0 \mathrm{a}$ & $0.59 \pm 0.0 \mathrm{~h}$ \\
\hline & & Fermented/adjusted pH & $0.85 \pm 0.0 \mathrm{ghij}$ & $0.10 \pm 0.0 \mathrm{~h}$ & $10.69 \pm 0.0$ bcdef & $0.42 \pm 0.0$ defg & ND \\
\hline & & Fermented/unadjusted $\mathrm{pH}$ & $0.85 \pm 0.0$ ghij & $0.10 \pm 0.0 \mathrm{~h}$ & $10.74 \pm 0.0$ bcdef & $0.52 \pm 0.1 \mathrm{abc}$ & ND \\
\hline
\end{tabular}

${ }^{a}$ Mean value \pm standard error. Different letters in each column represent statistically significant differences between sample extract $x$ fermentation time-point interactions $(p<0.05)$. 


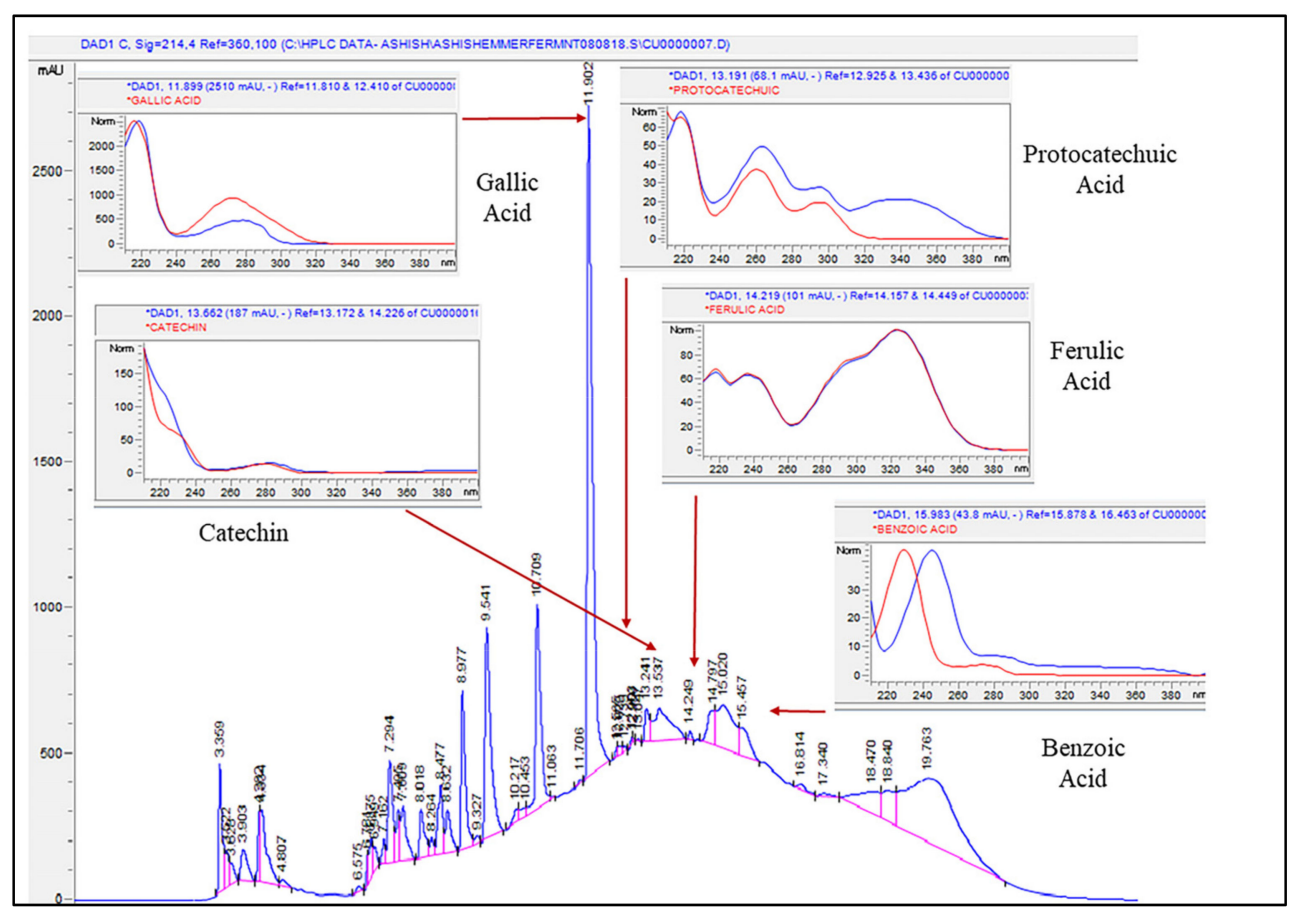

Figure 2. Chromatogram of detected phenolic compounds present in unfermented (control) and fermented (adjusted pH and unadjusted $\mathrm{pH})$ Emmer and Barlow wheat extracts $(0.4 \mathrm{~g} / \mathrm{mL})$ at $0,24,48$, and $72 \mathrm{~h}$ fermentation time points. Analysis was done using high-performance liquid chromatography (HPLC).

Among these phenolic compounds, higher concentrations of gallic acid (7.29 to $13 \mu \mathrm{g} / \mathrm{g}$ DW) and catechin $(0.1$ to $10.94 \mu \mathrm{g} / \mathrm{g}$ DW) were observed in both wheat extracts. The mean separation for all phenolic compounds was statistically significant between sample extracts, fermentation time points, and sample extract $\times$ fermentation time point interactions $(p<0.05)$. Overall, significantly higher benzoic acid content was observed in fermented wheat extracts when compared to the respective unfermented controls. Between sample extract $\times$ fermentation time point interactions, fermented Barlow without $\mathrm{pH}$ adjustment at $0-24 \mathrm{~h}$ had significantly higher benzoic acid content $(p<0.05)$. Among phenolic compounds, the catechin and ferulic acid content of both wheat samples declined significantly with fermentation, and ferulic acid content was not detected in the fermented samples at 24,48 , and $72 \mathrm{~h}$ (Table 1 ). In a previous study, whole grain, and milled fractions (flour, germ, and bran) of commercial soft and hard wheat varieties, were subjected to gastric conditions (low $\mathrm{pH}$ ), and the vanillic and ferulic acid content was found to be higher in the treated wheat samples when compared to the untreated (control) samples [37]. In another study, whole wheat co-fermented with L. plantarum and L. hammesii displayed phenolic acid metabolism, in which ferulic acid was released from the bound form via the action of L. hammesii, and the free ferulic acid was converted to dihydroferulic acid and other volatile compounds via the action of L. plantarum [38]. Similarly, the reduction of ferulic acid to dihydroferulic acid by L. plantarum and L. fermentum was also reported in another study [39]. The metabolism of phenolic compounds by LAB mostly dictates the changes in the phenolic composition in fermented food matrices and in many cases is based on the physio-chemical properties of the substrate, as well as the bacterial species or strains used in fermentation [40]. Additionally, changes in the ratio of soluble and insoluble dietary fiber during fermentation also influence the composition of free, bound, and conjugated phenolics in the fermented food matrix [41]. In the current study, unfermented Emmer at 24, 48, and $72 \mathrm{~h}$ fermentation time points had significantly higher gallic acid content, which declined slightly following fermentation $(p<0.05)$. Unfermented Barlow had higher protocatechuic acid content, but it was statistically at par with fermented extracts 
(unadjusted $\mathrm{pH}$ ), while in Emmer, higher protocatechuic acid was found in fermented extracts (without $\mathrm{pH}$ adjustment) at 48 and $72 \mathrm{~h}$ fermentation time points.

The results of this study indicate that the fermentation of wheat with LAB can significantly alter the content and composition of phenolics, specifically due to changes in $\mathrm{pH}$ and/or based on the microbial enzymatic action that occurs during fermentation. However, the increase or decrease in the concentration of phenolics and their related bioactivity are largely based on the structure-function relationship of specific phenolic compounds that are present in the food substrates. Such changes also dictate phenolic-linked functional properties of fermented foods, such as antioxidant, antihyperglycemic, and antimicrobial properties, and should be accounted for when designing health-targeted functional foods and ingredients.

\subsection{Total Antioxidant Activity}

The antioxidant property of the phenolic compounds of plant-based food substrates is relevant for its value-added utilization in dietary support strategies to help manage chronic oxidative stress and associated non-communicable diseases. Therefore, in vitro antioxidant assays were carried out to understand the overall antioxidant potential of fermented wheat extracts and was investigated in the context of soluble phenolic content and phenolic profile and its subsequent relevance to specific health functional targets. The antioxidant activity of fermented and unfermented wheat extracts was determined based on ABTS and DPPH free radical scavenging assays. Overall, higher mean antioxidant activity was observed with ABTS free radical scavenging assay, which ranged between $82-90 \%$ inhibition (similar range of antioxidant activity was also found in Trolox $(1.25 \mathrm{mg} / \mathrm{mL})$ (Figure 3A).

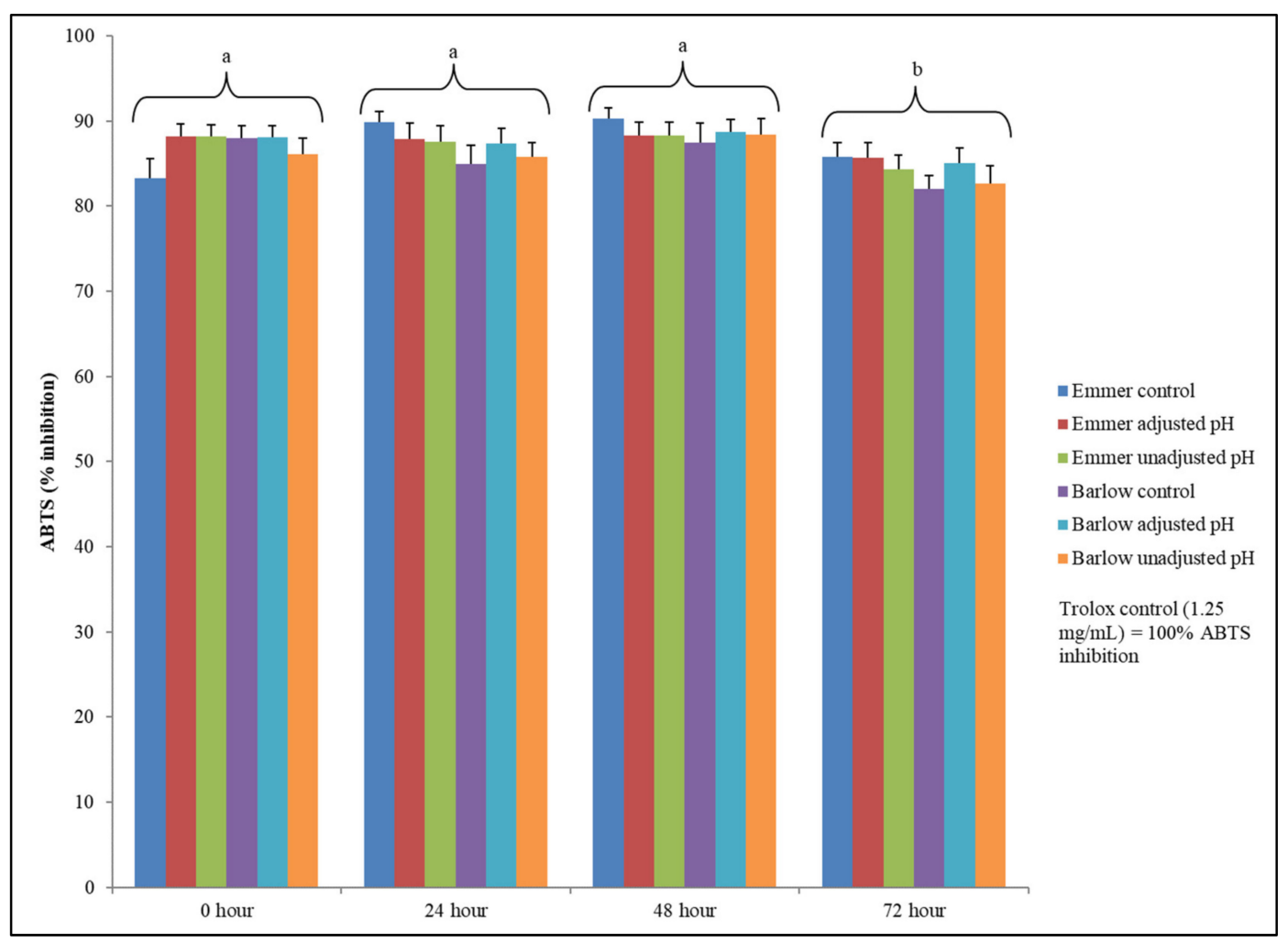

(A)

Figure 3. Cont. 


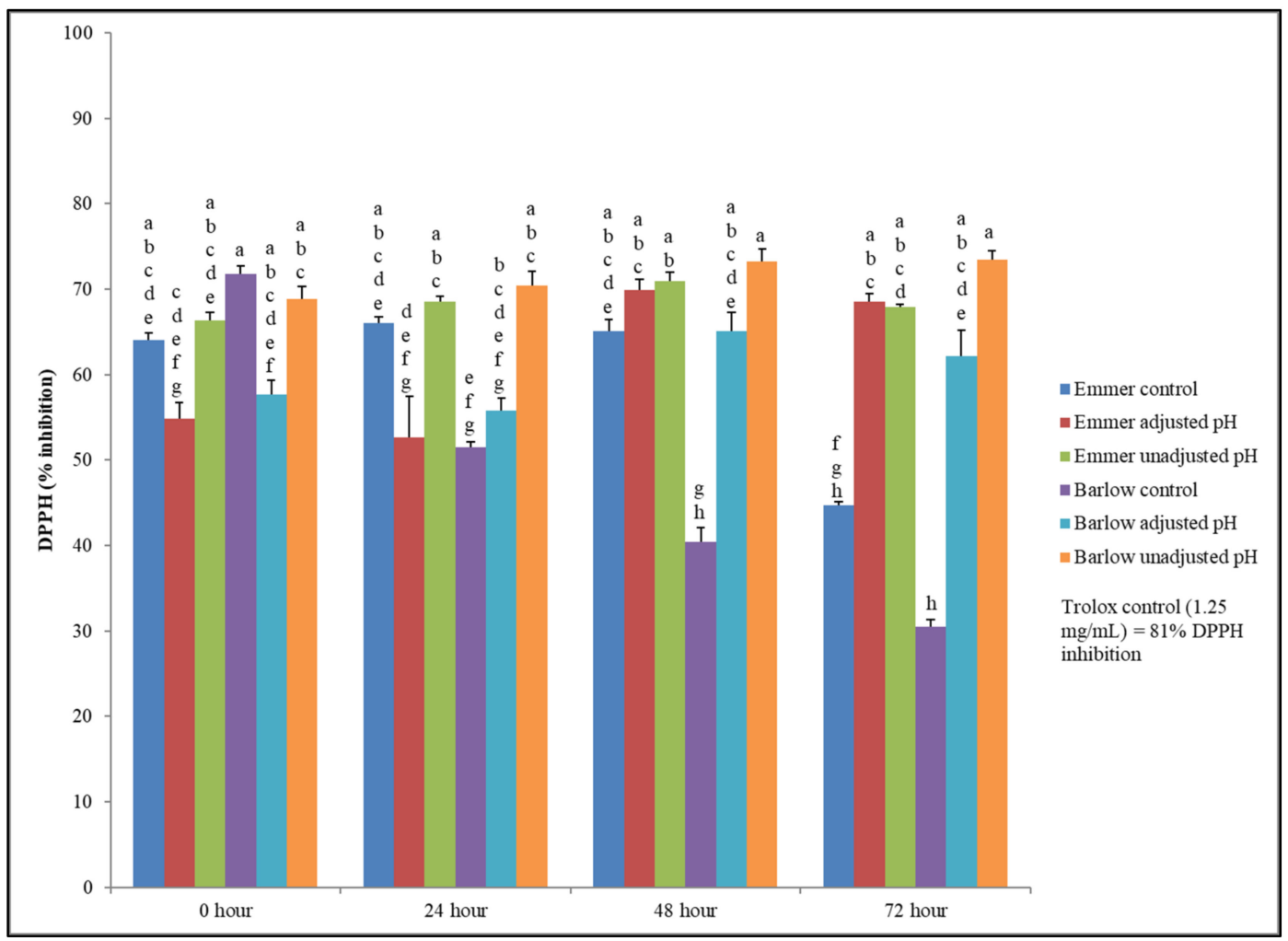

(B)

Figure 3. (A) Total antioxidant activity (ABTS free radical scavenging assay) of unfermented (control) and fermented (adjusted $\mathrm{pH}$ and unadjusted $\mathrm{pH}$ ) Emmer and Barlow wheat extracts $(0.4 \mathrm{~g} / \mathrm{mL}$ ) at $0,24,48$ and $72 \mathrm{~h}$ fermentation time points. Data is expressed as the mean \pm standard error. Different letters indicate statistically significant differences between fermentation time points $(p<0.05)$ (the effect of sample extract $\times$ fermentation time-point interactions was not significant for ABTS-based antioxidant activity). (B) Total antioxidant activity (DPPH free radical scavenging assay) of unfermented (control) and fermented (adjusted $\mathrm{pH}$ and unadjusted $\mathrm{pH}$ ) Emmer and Barlow wheat extracts $(0.4 \mathrm{~g} / \mathrm{mL}$ ) at $0,24,48$, and $72 \mathrm{~h}$ fermentation time points. Data is expressed as the mean \pm standard error. Different letters indicate statistically significant differences between sample extract $\times$ fermentation time point interactions $(p<0.05)$.

Statistically significant differences in ABTS scavenging activity were observed only between fermentation time points and not between sample extracts or sample extract $\times$ fermentation time point interactions (Figure 3A). Between fermentation time points, higher ABTS-based antioxidant activity was observed at 24 and $48 \mathrm{~h}$, and it was statistically significant when compared to the antioxidant activity of the fermented and unfermented samples at $72 \mathrm{~h}$ $(p<0.05)$. The reason for not finding statistically significant differences in ABTS-based antioxidant activity among fermented and unfermented sample extracts might be due to the equally high saturated levels of mean antioxidant activity across all samples. In general, ABTS free radicals have a higher affinity towards hydrophilic antioxidants, and the results of this study indicate that fermented and unfermented aqueous extracts of wheat substrates might have equally high concentration of water-soluble antioxidants, which are amenable to the ABTS radical scavenging activity. The mean antioxidant activity of fermented and unfermented wheat extracts for the DPPH free radical scavenging assay was relatively lower (30-72\% inhibition) when compared to the result of the ABTS assay (Figure 3B).

The difference of results in antioxidant activity between the DPPH and ABTS radical scavenging activity could be due to the chemical structure of the synthetic radicals as DPPH being a more stable radical, takes a longer time to decolorize when compared to ABTS, and in addition, their differences in affinity towards hydrophilic and lipophilic antioxidants can also affect the inhibition response. However, statistically significant differences in DPPH scavenging activity were observed between sample extracts, fermentation time points, 
and sample extract $\times$ fermentation time point interactions $(p<0.05)$. At $0 \mathrm{~h}$ time point, unfermented Barlow had higher DPPH-based antioxidant activity, while at 24, 48, and $72 \mathrm{~h}$ time points, significantly $(p<0.05)$ higher antioxidant activity was observed in fermented sample extracts and specifically, in unadjusted $\mathrm{pH}$ (naturally acidic) extracts. Similarly, at $72 \mathrm{~h}$ time point, statistically higher DPPH-based antioxidant activity was also observed in fermented Emmer extracts (both with and without $\mathrm{pH}$ adjustments) when compared to the antioxidant activity of unfermented Emmer. Overall, the antioxidant activity of unfermented wheat extracts declined significantly from 0 to $72 \mathrm{~h}$. However, with LAB fermentation, antioxidant activity of both wheat extracts improved and was sustained at higher levels even after fermentation for $72 \mathrm{~h}$. The values of the DPPH radical scavenging activity for the unfermented emmer and Barlow wheat extracts reported in this study was slightly higher when compared to the result of our previous study [21]. As in the case of TSP content, the antioxidant activity of grains also varies between different crop years and locations, which is mostly because of different environmental factors contributing to the biosynthesis and distribution of stress-protective bioactive phenolic compounds and antioxidant enzymes at the pre-harvest production stages [34-36].

In a previous published study, whole grain, and milled fractions (flour, germ, and bran) of commercial soft and hard wheat varieties were subjected to gastric conditions (low $\mathrm{pH}$ ), and the total antioxidant activity was found to be significantly higher in the treated samples, when compared to the untreated (control) samples $(p<0.05)$ [37]. The fermentation of whole grains (e.g., wheat, oats, barley, rye, sorghum, and millet) with LAB can potentially improve the total phenolic content and antioxidant activity of the grains through microbial enzymatic activity, which results in the breakdown of the cell wall of the grains and the release of bound bioactive compounds with antioxidant potential [42]. The improved antioxidant activity (DPPH-based) in LAB-fermented wheat extracts found in the current study has significant relevance for its wider health-targeted food and ingredient applications, especially to counter chronic oxidative stress and associated diseases, such as type 2 diabetes, cardiovascular diseases, and dyslipidemia. However, it is important to validate this finding by conducting in vivo model-based studies and by investigating other functional properties, such as the antihyperglycemic, antihypertensive, and antimicrobial functionalities of LAB-fermented wheat extracts.

\subsection{AntiHyperglycemic Property Relevant $\alpha$-Amylase and $\alpha$-Glucosidase Enzyme Inhibitory Activities}

Managing glucose homeostasis by slowing down the breakdown of soluble dietary carbohydrates and restricting subsequent glucose uptake into the bloodstream is critical to counter the chronic hyperglycemia commonly associated with early stages of type 2 diabetes. Therefore, many dietary and therapeutic strategies target the inhibition of key enzymes, like $\alpha$-amylase and $\alpha$-glucosidase, which are involved in carbohydrate metabolism, to slow down the release and absorption of glucose during the post-prandial phase. To understand these antihyperglycemic benefit-relevant metabolic targets, we determined the $\alpha$-amylase and $\alpha$-glucosidase enzyme inhibitory activities of fermented and unfermented wheat extracts using rapid in vitro assay models. Very high (which was equivalent to the result of positive control -acarbose $(10 \mathrm{mg} / \mathrm{mL}) \alpha$-amylase enzyme inhibitory activity was observed across all wheat sample extracts $(0.4 \mathrm{~g} / \mathrm{mL})$ and at different fermentation time points (Table 2). 
Table 2. Antihyperglycemic property relevant $\alpha$-amylase and $\alpha$-glucosidase (\%) enzyme inhibitory activity of unfermented and fermented wheat extracts (0.4g/mL).

\begin{tabular}{|c|c|c|c|c|c|c|c|c|}
\hline $\begin{array}{l}\text { Time Point } \\
\text { (Hours) }\end{array}$ & $\begin{array}{l}\text { Sample } \\
\text { Extract }^{\text {a }}\end{array}$ & & & $\begin{array}{l}\alpha \text {-Amylase } \\
\text { Inhibition }\end{array}$ & & & $\begin{array}{l}\alpha \text {-Glucosidase } \\
\text { Inhibition }\end{array}$ & \\
\hline \multirow{4}{*}{0} & \multirow{4}{*}{ Emmer } & & Undiluted & 1:2 diluted & 1:5 diluted & Undiluted & 1:2 diluted & 1:5 diluted \\
\hline & & Unfermented & $90.9 \pm 1.4 a$ & $79.5 \pm 1.1 \mathrm{abcd}$ & $75.2 \pm 0.8 \mathrm{ab}$ & $34.7 \pm 1.5 \mathrm{efgh}$ & $23.2 \pm 1.1$ defg & $11.9 \pm 0.8 \mathrm{defg}$ \\
\hline & & Fermented/adjusted pH & $94.4 \pm 2.1 \mathrm{a}$ & $79.4 \pm 1.1 \mathrm{abcd}$ & $75.6 \pm 1.5 a$ & $26.3 \pm 1.3 \mathrm{hij}$ & $14.2 \pm 1.2 \mathrm{hi}$ & $7.4 \pm 0.7 \mathrm{hijk}$ \\
\hline & & Fermented/unadjusted $\mathrm{pH}$ & $91.8 \pm 1.2 \mathrm{a}$ & $84.6 \pm 0.8 \mathrm{ab}$ & $80.9 \pm 1.7 a$ & $37.6 \pm 5.9 \mathrm{efg}$ & $21.0 \pm 0.9 \mathrm{efg}$ & $9.4 \pm 0.6$ fghij \\
\hline \multirow{6}{*}{24} & \multirow[t]{3}{*}{ Barlow } & Unfermented & $93.2 \pm 1.5 \mathrm{a}$ & $89.9 \pm 1.0 \mathrm{a}$ & $79.9 \pm 1.7 \mathrm{a}$ & $29.1 \pm 0.9 \mathrm{fghi}$ & $20.7 \pm 0.5 \mathrm{fg}$ & $9.9 \pm 0.4$ efghi \\
\hline & & Fermented/adjusted pH & $92.9 \pm 2.9 a$ & $83.1 \pm 1.6 \mathrm{abc}$ & $79.7 \pm 1.2 \mathrm{a}$ & $20.9 \pm 0.8 \mathrm{ijk}$ & $13.5 \pm 0.8 \mathrm{hi}$ & $5.6 \pm 0.8 \mathrm{ijklm}$ \\
\hline & & Fermented/unadjusted $\mathrm{pH}$ & $94.7 \pm 1.2 \mathrm{a}$ & $88.3 \pm 1.6 \mathrm{ab}$ & $82.0 \pm 1.9 a$ & $28.1 \pm 0.9$ ghi & $16.9 \pm 0.9 \mathrm{gh}$ & $7.0 \pm 0.8 \mathrm{hijkl}$ \\
\hline & \multirow[t]{3}{*}{ Emmer } & Unfermented & $85.2 \pm 1.9 \mathrm{ab}$ & $79.2 \pm 1.7 \mathrm{abcd}$ & $66.7 \pm 1.8 \mathrm{abcd}$ & $41.2 \pm 0.7 \mathrm{def}$ & $27.3 \pm 0.8$ cde & $16.9 \pm 0.6 b c$ \\
\hline & & Fermented/adjusted pH & $68.6 \pm 1.0 \mathrm{~cd}$ & $60.6 \pm 0.3$ cdefg & $51.6 \pm 0.7 \mathrm{defgh}$ & $15.6 \pm 0.7 \mathrm{kl}$ & $8.8 \pm 0.6 \mathrm{ijk}$ & $4.2 \pm 0.4 \mathrm{klmn}$ \\
\hline & & Fermented/unadjusted $\mathrm{pH}$ & $91.2 \pm 0.8 \mathrm{a}$ & $53.2 \pm 0.7$ efgh & $49.2 \pm 2.2 \mathrm{efgh}$ & $48.6 \pm 1.2 \mathrm{bcd}$ & $24.1 \pm 0.9 \mathrm{def}$ & $9.6 \pm 0.5$ fghi \\
\hline $\begin{array}{l}\text { Time Point } \\
\text { (Hours) }\end{array}$ & \multicolumn{2}{|l|}{$\begin{array}{l}\text { Sample } \\
\text { Extract }^{\text {a }}\end{array}$} & & \multicolumn{2}{|l|}{$\begin{array}{l}\alpha \text {-Amylase } \\
\text { Inhibition }\end{array}$} & & \multicolumn{2}{|l|}{$\begin{array}{l}\alpha \text {-Glucosidase } \\
\text { Inhibition }\end{array}$} \\
\hline \multirow{10}{*}{48} & \multirow{4}{*}{ Barlow } & & Undiluted & 1:2 diluted & 1:5 diluted & Undiluted & 1:2 diluted & 1:5 diluted \\
\hline & & Unfermented & $91.4 \pm 1.7 \mathrm{a}$ & $80.9 \pm 1.2 \mathrm{abcd}$ & $71.5 \pm 1.3 \mathrm{abc}$ & $33.4 \pm 0.7 \mathrm{fgh}$ & $22.2 \pm 0.4 \mathrm{defg}$ & $11.9 \pm 0.5 \mathrm{defg}$ \\
\hline & & Fermented/adjusted pH & $62.0 \pm 0.8 \mathrm{de}$ & $47.2 \pm 0.8 \mathrm{fgh}$ & $35.8 \pm 1.4 \mathrm{hij}$ & $9.2 \pm 0.51$ & $4.8 \pm 0.4 \mathrm{jk}$ & $0.8 \pm 0.3 n$ \\
\hline & & Fermented/unadjusted $\mathrm{pH}$ & $85.3 \pm 0.5 \mathrm{ab}$ & $59.8 \pm 0.9 \mathrm{defg}$ & $39.5 \pm 1.0 \mathrm{ghi}$ & $40.8 \pm 1.3 \mathrm{def}$ & $19.5 \pm 0.5 \mathrm{fgh}$ & $4.4 \pm 0.9 \mathrm{klmn}$ \\
\hline & \multirow[t]{3}{*}{ Emmer } & Unfermented & $87.3 \pm 2.4 \mathrm{ab}$ & $74.9 \pm 0.9$ abcde & $58.4 \pm 3.5 \mathrm{bcdef}$ & $43.7 \pm 1.7 \mathrm{cde}$ & $33.9 \pm 0.9 \mathrm{ab}$ & $20.2 \pm 0.6 \mathrm{ab}$ \\
\hline & & Fermented/adjusted pH & $24.4 \pm 2.7 \mathrm{~g}$ & $14.2 \pm 1.9 \mathrm{ij}$ & $2.5 \pm 0.9 \mathrm{k}$ & $13.7 \pm 0.4 \mathrm{kl}$ & $5.2 \pm 0.9 \mathrm{jk}$ & $3.3 \pm 0.5 \mathrm{klmn}$ \\
\hline & & Fermented/unadjusted $\mathrm{pH}$ & $92.9 \pm 0.9 \mathrm{a}$ & $78.1 \pm 1.0 \mathrm{abcd}$ & $2.6 \pm 1.2 \mathrm{k}$ & $57.2 \pm 1.9 \mathrm{ab}$ & $31.8 \pm 0.8 \mathrm{abc}$ & $11.4 \pm 0.7 \mathrm{defgh}$ \\
\hline & \multirow[t]{3}{*}{ Barlow } & Unfermented & $85.5 \pm 1.4 \mathrm{ab}$ & $73.3 \pm 2.9$ abcde & $67.6 \pm 2.8 \mathrm{abcd}$ & $36.9 \pm 0.7 \mathrm{efg}$ & $24.7 \pm 0.7 \mathrm{def}$ & $14.0 \pm 0.8 \mathrm{cde}$ \\
\hline & & Fermented/adjusted pH & $54.9 \pm 1.4 \mathrm{def}$ & $40.8 \pm 1.3 \mathrm{gh}$ & $28.3 \pm 1.4 \mathrm{ij}$ & $9.2 \pm 0.41$ & $3.1 \pm 0.6 \mathrm{k}$ & $1.5 \pm 0.3 \mathrm{mn}$ \\
\hline & & Fermented/unadjusted $\mathrm{pH}$ & $90.2 \pm 1.2 \mathrm{ab}$ & $66.5 \pm 1.0 \mathrm{bcdef}$ & $41.7 \pm 0.5$ fghi & $53.3 \pm 0.9 \mathrm{bc}$ & $28.2 \pm 0.8 \mathrm{bcd}$ & $12.2 \pm 1.1 \mathrm{defg}$ \\
\hline $\begin{array}{l}\text { Time Point } \\
\text { (Hours) }\end{array}$ & \multicolumn{2}{|l|}{$\begin{array}{l}\text { Sample } \\
\text { Extract }^{\text {a }}\end{array}$} & & \multicolumn{2}{|l|}{$\begin{array}{l}\alpha \text {-Amylase } \\
\text { Inhibition }\end{array}$} & & \multicolumn{2}{|l|}{$\begin{array}{l}\alpha \text {-Glucosidase } \\
\text { Inhibition }\end{array}$} \\
\hline \multirow{8}{*}{72} & \multirow{3}{*}{ Emmer } & & Undiluted & 1:2 diluted & 1:5 diluted & Undiluted & 1:2 diluted & 1:5 diluted \\
\hline & & Unfermented & $86.8 \pm 2.3 \mathrm{ab}$ & $72.1 \pm 1.7 \mathrm{abcde}$ & $54.5 \pm 6.2 \mathrm{cdefg}$ & $49.3 \pm 0.5 \mathrm{bcd}$ & $36.9 \pm 0.5 a$ & $22.4 \pm 0.5 a$ \\
\hline & & Fermented/adjusted pH & $9.6 \pm 0.9 \mathrm{~h}$ & $1.8 \pm 0.7 \mathrm{j}$ & $0.2 \pm 0.2 \mathrm{k}$ & $16.3 \pm 0.6 \mathrm{jkl}$ & $9.4 \pm 0.5 \mathrm{ij}$ & $5.1 \pm 0.5 \mathrm{jklmn}$ \\
\hline & \multirow{4}{*}{ Barlow } & Fermented/unadjusted $\mathrm{pH}$ & $91.8 \pm 0.8 \mathrm{a}$ & $82.8 \pm 0.6 \mathrm{abc}$ & $2.6 \pm 0.6 \mathrm{k}$ & $64.5 \pm 1.1 \mathrm{a}$ & $34.9 \pm 0.6 \mathrm{a}$ & $13.8 \pm 0.9 \mathrm{cdef}$ \\
\hline & & Unfermented & $78.1 \pm 1.7 \mathrm{bc}$ & $70.7 \pm 9.6 \mathrm{abcde}$ & $66.4 \pm 3.4 \mathrm{abcde}$ & $41.6 \pm 0.9 \mathrm{def}$ & $28.4 \pm 0.9 \mathrm{bcd}$ & $15.4 \pm 0.5 \mathrm{~cd}$ \\
\hline & & Fermented/adjusted pH & $49.2 \pm 1.7 \mathrm{f}$ & $34.4 \pm 2.3 \mathrm{hi}$ & $21.6 \pm 1.1 \mathrm{j}$ & $11.5 \pm 0.7 \mathrm{kl}$ & $5.8 \pm 0.7 \mathrm{jk}$ & $2.9 \pm 0.6 \mathrm{lmn}$ \\
\hline & & Fermented/unadjusted $\mathrm{pH}$ & $91.5 \pm 1.1 \mathrm{a}$ & $75.5 \pm 1.3$ abcde & $40.0 \pm 1.4 \mathrm{ghi}$ & $58.2 \pm 0.9 \mathrm{ab}$ & $27.7 \pm 1.1 \mathrm{bcd}$ & $9.2 \pm 1.1 \mathrm{ghij}$ \\
\hline & $\begin{array}{l}\text { Acarbose } \\
\text { control }\end{array}$ & $10 \mathrm{mg} / \mathrm{mL}$ & 89 & & & 63 & & \\
\hline
\end{tabular}

${ }^{a}$ Mean value \pm standard error. Different letters in each column represent statistically significant differences between sample extract $\times$ fermentation time-point interactions $(p<0.05)$. 
Additionally, significant dose-dependent responses (undiluted, half, and one-fifth diluted) in $\alpha$-amylase enzyme inhibitory activity were observed in all wheat sample extracts. The mean differences between sample extracts, fermentation time points, and sample extract $\times$ fermentation time point interactions for the undiluted, half, and onefifth diluted extracts were also statistically significant $(p<0.05)$. The undiluted extracts, fermented Barlow, and Emmer without $\mathrm{pH}$ adjustment at different fermentation time points had higher $\alpha$-amylase enzyme inhibitory activity, when compared to the fermented wheat extracts with $\mathrm{pH}$ adjustment $(p<0.05)$. However, the value of the $\alpha$-amylase enzyme inhibitory activity of fermented extracts without $\mathrm{pH}$ adjustment was statistically at par with unfermented wheat extracts. This similar trend and statistically significant differences in $\alpha$-amylase enzyme inhibitory activity between sample extract $\times$ fermentation time point interactions were also observed for the half and one-fifth diluted extracts in a dosedependent manner $(p<0.05)$. The results indicate that the acidic $\mathrm{pH}$ of the fermented wheat extracts directly interfered with the in vitro assay mechanism, which resulted in higher $\alpha$-amylase enzyme inhibitory activity in $\mathrm{pH}$-unadjusted wheat extracts. However, at 0 and $24 \mathrm{~h}$ time points, fermented wheat extracts with adjusted $\mathrm{pH}$ also had moderate to high $\alpha$-amylase enzyme inhibitory activity relevant for dietary interventions targeting antihyperglycemic benefits.

Like the results of $\alpha$-amylase enzyme inhibitory activity, a significant effect of acidic $\mathrm{pH}$ on $\alpha$-glucosidase enzyme inhibitory activity was also observed. Overall, low to moderate $\alpha$-glucosidase enzyme inhibitory activity was observed in fermented and unfermented wheat extracts, which was equivalent to positive control acarbose $(10 \mathrm{mg} / \mathrm{mL})$ (Table 2). The variations in $\alpha$-glucosidase enzyme inhibitory activity between sample extracts, fermentation time points, and sample extract $\times$ fermentation time point interactions were statistically significant for the undiluted, half, and one-fifth diluted extracts $(p<0.05)$. In the undiluted extracts, fermented Emmer (without $\mathrm{pH}$ adjustment) at the $72 \mathrm{~h}$ time point had significantly higher $\alpha$-glucosidase inhibitory activity when compared to the unfermented control $(p<0.05)$. Like the results of Emmer, higher $\alpha$-glucosidase enzyme inhibitory activity was also observed in undiluted extracts of fermented Barlow (without $\mathrm{pH}$ adjustment) when compared to the unfermented and fermented (with $\mathrm{pH}$ adjustment) extracts at 24,48 , and $72 \mathrm{~h}$ time points. The results of mean $\alpha$-amylase and $\alpha$-glucosidase enzyme inhibitory activity of wheat extracts were slightly higher than the results obtained in our previous study [21]. Overall, the results of the current study indicated that, at the natural acidic $\mathrm{pH}, \mathrm{LAB}$-fermented wheat extracts are good dietary sources that can be integrated and targeted in dietary interventions to manage post-prandial blood glucose level. The release of bioactive compounds, such as phenolics in a fermented food matrix and changes in their functional properties under certain physio-chemical condition (acidic environment), might have greater influence on their overall functional properties including antihyperglycemic function. However, further studies with different wheat-based substrate sources (from multiple locations, different crop years, and genetic backgrounds) and different LAB species and strains are needed to optimize and develop wheat-based fermented foods and functional ingredients targeting type 2 diabetes benefits.

\subsection{Antimicrobial and Prebiotic Activity}

In addition to the antihyperglycemic functional benefits, potential antibacterial activity of fermented and unfermented wheat extracts against gastric ulcer causing pathogenic bacteria $H$. pylori was investigated using agar disc diffusion assay. The antibacterial activity was measured and expressed in millimeters based on the width of the zone of no growth around the discs. In this study, zones of inhibition were observed with fermented Emmer and Barlow (unadjusted $\mathrm{pH}$ ) at the $72 \mathrm{~h}$ time point, and the width of the zones of inhibition ranged between 2 to $4 \mathrm{~mm}$ (Figure 4). 


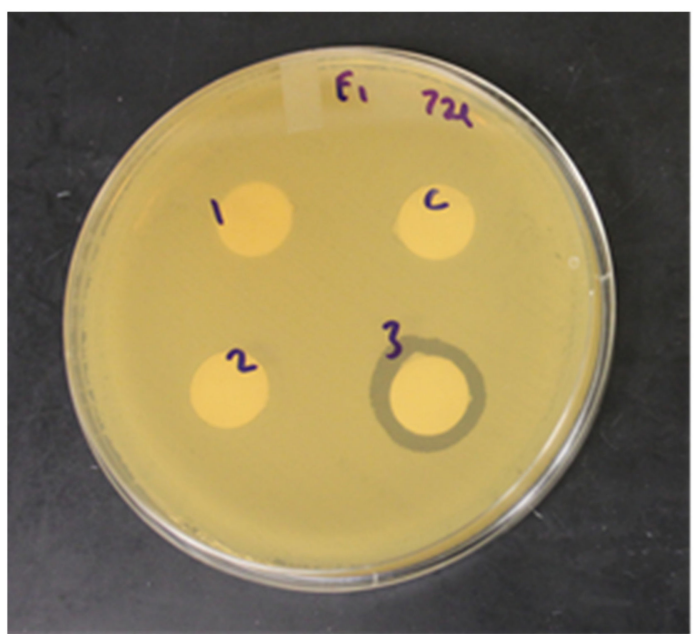

(a)

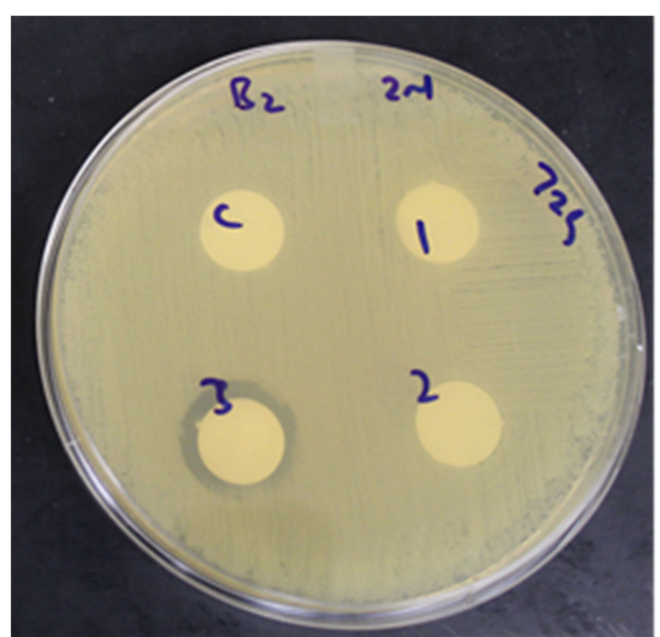

(b)

Figure 4. Antibacterial activity of wheat extracts against H. pylori. (a) Unfermented (control) and fermented (adjusted pH and unadjusted $\mathrm{pH}$ ) Emmer wheat extracts $(0.4 \mathrm{mg} / \mathrm{mL}$ ) at the $72 \mathrm{~h}$ fermentation time point. (b) Unfermented (control) and fermented (adjusted $\mathrm{pH}$ and unadjusted $\mathrm{pH}$ ) Barlow wheat extracts at $72 \mathrm{~h}$ fermentation time point. Zone of inhibition was measured in millimeters. C- water (control), 1- unfermented, 2- fermented (adjusted pH), 3- fermented (unadjusted pH).

LAB produces bacteriocins, which, in combination with weak organic acids (lactic acid) and a low $\mathrm{pH}$, can contribute to the inhibition of non-acidogenic or non-aciduric bacterial pathogens $[43,44]$. These bacteriocins permeabilize the bacterial cell membrane leading to cellular leakage, while uncharged lipophilic weak organic acids produced during LAB growth can translocate into the cell, where it disassociates into protons and anions. The protons lead to the acidification of the cell cytoplasm, causing the denaturation of proteins and bacterial DNA, while the anions cause osmotic stress to the bacterial cell [44-46]. Since the L. plantarum strain used in this study is not reported to produce bacteriocins and antimicrobial activity was observed only for the fermented extracts (without $\mathrm{pH}$ adjustment), the results indicate that the conditions of a low $\mathrm{pH}$ (acidic environment) in combination with weak organic acids like lactic acid, combined with phenolic compounds, could have contributed to the inhibition of H. pylori. However, H. pylori can survive in the acidic environment of its natural habitat, the gastric mucosa, due the secretion of the bacterial enzyme urease, which hydrolyzes the urea that is present under physiological conditions in acidic medium [47]. The ammonia produced during hydrolysis can act as a receptor for $\mathrm{H}+$ ions, consequently generating a neutral $\mathrm{pH}$, which is required for the survival of the bacterium [47]. Apart from low $\mathrm{pH}$ and weak organic acid production, another explanation for the anti-H. pylori activity of the fermented extracts in the current study could be the antimicrobial activity of phenolic compounds present in the extracts, which could potentially regulate the cellular redox response through the proline-associated pentose phosphate pathway $[48,49]$. In general, plant secondary metabolites, such as phenolic compounds, display potential antimicrobial activity against bacterial pathogens through a variety of mechanisms, which include the inhibition of DNA or protein synthesis, the inhibition of important microbial biosynthetic pathways (e.g., folic acid biosynthesis), the loss of cell-membrane integrity, leading to cell lysis, and a reduction in the availability of micronutrients needed for microbial growth [50-55]. Furthermore, phenolic compounds such as flavonoids can inhibit the activity of the urease enzyme and other virulence factors involved in the pathogenesis of H. pylori [47]. In a previous study, gallic acid and catechin were found to inhibit the growth of two H. pylori strains in a dose-dependent manner, with gallic acid showing a stronger inhibitory activity than catechin, and a partial additive growth inhibitory effect was observed when gallic and catechin were used in combination [56]. It is possible that in the current study, the low $\mathrm{pH}$ and production of weak organic acids during LAB fermentation enhanced the antimicrobial activity of 
these phenolic compounds that were present in wheat extracts against $H$. pylori. This is supported by the observation that only the fermented Emmer and Barlow extracts (without $\mathrm{pH}$ adjustment) displayed anti-H. pylori activity, while the unfermented and fermented (with $\mathrm{pH}$ adjustment) extracts did not any show antimicrobial activity. Additionally, there was no substantial change in TSP content during the fermentation period, indicating the possible role of phenolic compounds in the anti- $\mathrm{H}$. pylori activity. Therefore, $72 \mathrm{~h}$ fermented Emmer and Barlow with natural acidic $\mathrm{pH}$ is relevant to potentially counter H. pylori-induced gastric ulcer, a common prevalent gut infection around the globe.

To target designed bioactive-enriched food substrates for human gut health benefits, it is also important to understand whether examples such as fermented wheat extracts in this study have any negative impact on beneficial gut microbes or not. To evaluate this potential, the growth of $B$. longum with unfermented and fermented wheat extracts was investigated and compared using a LAB proliferation prebiotic assay. The growth of B. longum ranged from 4.9 to $5.5 \log \mathrm{CFU} / \mathrm{mL}, 4.4$ to $6.8 \log \mathrm{CFU} / \mathrm{mL}, 7.7$ to $8.5 \log$ $\mathrm{CFU} / \mathrm{mL}, 8.9$ to $9.5 \log \mathrm{CFU} / \mathrm{mL}$, and 8.9 to $9.6 \log \mathrm{CFU} / \mathrm{mL}$ at the respective $0,6,12,24$, and $48 \mathrm{~h}$ time points of the proliferation assay (Table 3 ).

Table 3. Prebiotic activity ( $\log \mathrm{CFU} / \mathrm{mL})$ of unfermented and fermented wheat extracts $(0.4 \mathrm{mg} / \mathrm{mL})$ for growth of Bifidobacterium longum.

\begin{tabular}{|c|c|c|c|c|c|c|c|}
\hline $\begin{array}{l}\text { Time Point } \\
\text { (Hours) }\end{array}$ & $\begin{array}{l}\text { Sample } \\
\text { Extract }^{\text {a }}\end{array}$ & & 0 Hour $^{b}$ & 6 Hour $^{b}$ & 12 Hour $^{b}$ & 24 Hour $^{b}$ & 48 Hour $^{b}$ \\
\hline \multirow[t]{7}{*}{0} & Assay control & & $4.9 \pm 0.3$ & $4.7 \pm 1.6$ & $8.1 \pm 0.2$ & $9.5 \pm 0.0$ & $9.5 \pm 0.2$ \\
\hline & Emmer & Unfermented & $5.1 \pm 0.2$ & $6.3 \pm 0.2$ & $8.5 \pm 0.0$ & $9.5 \pm 0.0$ & $9.4 \pm 0.1$ \\
\hline & & Fermented/adjusted $\mathrm{pH}$ & $5.4 \pm 0.1$ & $4.7 \pm 1.6$ & $8.4 \pm 0.1$ & $9.2 \pm 0.1$ & $9.2 \pm 0.2$ \\
\hline & & Fermented/unadjusted $\mathrm{pH}$ & $5.4 \pm 0.1$ & $5.9 \pm 0.3$ & $8.4 \pm 0.1$ & $9.2 \pm 0.2$ & $9.6 \pm 0.1$ \\
\hline & Barlow & Unfermented & $4.9 \pm 0.3$ & $6.5 \pm 0.1$ & $8.2 \pm 0.1$ & $9.5 \pm 0.0$ & $9.6 \pm 0.0$ \\
\hline & & Fermented/adjusted $\mathrm{pH}$ & $5.3 \pm 0.2$ & $6.0 \pm 0.2$ & $8.2 \pm 0.2$ & $9.4 \pm 0.1$ & $9.3 \pm 0.3$ \\
\hline & & Fermented/unadjusted $\mathrm{pH}$ & $5.4 \pm 0.1$ & $4.4 \pm 1.5$ & $8.3 \pm 0.1$ & $9.4 \pm 0.1$ & $9.4 \pm 0.1$ \\
\hline \multirow[t]{2}{*}{24} & Assay control & & $5.1 \pm 0.3$ & $6.5 \pm 0.1$ & $8.3 \pm 0.0$ & $9.0 \pm 0.1$ & $9.1 \pm 0.1$ \\
\hline & Emmer & Unfermented & $5.5 \pm 0.0$ & $6.6 \pm 0.1$ & $8.3 \pm 0.1$ & $9.2 \pm 0.1$ & $9.0 \pm 0.1$ \\
\hline $\begin{array}{l}\text { Time Point } \\
\text { (Hours) }\end{array}$ & $\begin{array}{l}\text { Sample } \\
\text { Extract }\end{array}$ & & 0 hour $^{b}$ & 6 hour $^{b}$ & 12 hour $^{b}$ & 24 hour $^{\text {b }}$ & 48 hour $^{b}$ \\
\hline \multirow{10}{*}{48} & & Fermented/adjusted pH & $5.5 \pm 0.1$ & $6.8 \pm 0.1$ & $8.2 \pm 0.1$ & $8.9 \pm 0.0$ & $9.1 \pm 0.2$ \\
\hline & & Fermented/unadjusted $\mathrm{pH}$ & $5.6 \pm 0.1$ & $6.6 \pm 0.1$ & $8.2 \pm 0.1$ & $9.2 \pm 0.2$ & $8.9 \pm 0.4$ \\
\hline & Barlow & Unfermented & $5.5 \pm 0.1$ & $6.5 \pm 0.2$ & $8.4 \pm 0.1$ & $9.1 \pm 0.1$ & $8.9 \pm 0.1$ \\
\hline & & Fermented/adjusted $\mathrm{pH}$ & $5.5 \pm 0.1$ & $6.4 \pm 0.2$ & $8.3 \pm 0.1$ & $9.4 \pm 0.1$ & $9.2 \pm 0.1$ \\
\hline & & Fermented/unadjusted $\mathrm{pH}$ & $5.5 \pm 0.1$ & $6.3 \pm 0.2$ & $8.3 \pm 0.1$ & $9.2 \pm 0.1$ & $9.6 \pm 0.0$ \\
\hline & Assay control & & $5.5 \pm 0.1$ & $6.5 \pm 0.1$ & $8.3 \pm 0.1$ & $9.2 \pm 0.1$ & $9.2 \pm 0.2$ \\
\hline & Emmer & Unfermented & $5.1 \pm 0.1$ & $5.9 \pm 0.1$ & $8.1 \pm 0.3$ & $9.4 \pm 0.1$ & $9.3 \pm 0.0$ \\
\hline & & Fermented/adjusted $\mathrm{pH}$ & $5.4 \pm 0.1$ & $5.9 \pm 0.4$ & $7.9 \pm 0.4$ & $9.4 \pm 0.1$ & $9.4 \pm 0.1$ \\
\hline & & Fermented/unadjusted $\mathrm{pH}$ & $5.2 \pm 0.2$ & $4.8 \pm 1.6$ & $8.4 \pm 0.1$ & $9.3 \pm 0.2$ & $9.0 \pm 0.3$ \\
\hline & Barlow & Unfermented & $5.4 \pm 0.1$ & $6.6 \pm 0.1$ & $8.4 \pm 0.0$ & $9.3 \pm 0.2$ & $9.4 \pm 0.1$ \\
\hline $\begin{array}{l}\text { Time Point } \\
\text { (Hours) }\end{array}$ & $\begin{array}{l}\text { Sample } \\
\text { Extract }^{\text {a }}\end{array}$ & & 0 hour $^{b}$ & 6 hour $^{b}$ & 12 hour $^{b}$ & 24 hour $^{\text {b }}$ & 48 hour $^{b}$ \\
\hline \multirow{9}{*}{72} & & Fermented/adjusted pH & $5.5 \pm 0.1$ & $4.8 \pm 1.6$ & $8.3 \pm 0.1$ & $9.2 \pm 0.1$ & $9.3 \pm 0.1$ \\
\hline & & Fermented/unadjusted $\mathrm{pH}$ & $5.5 \pm 0.1$ & $6.4 \pm 0.1$ & $8.5 \pm 0.1$ & $9.1 \pm 0.2$ & $9.3 \pm 0.1$ \\
\hline & Assay control & & $5.1 \pm 0.2$ & $6.1 \pm 0.2$ & $7.7 \pm 0.5$ & $9.3 \pm 0.1$ & $9.5 \pm 0.1$ \\
\hline & Emmer & Unfermented & $5.4 \pm 0.1$ & $6.0 \pm 0.3$ & $8.0 \pm 0.4$ & $9.4 \pm 0.1$ & $9.5 \pm 0.1$ \\
\hline & & Fermented/adjusted pH & $5.5 \pm 0.2$ & $5.9 \pm 0.2$ & $8.4 \pm 0.2$ & $9.3 \pm 0.1$ & $9.5 \pm 0.2$ \\
\hline & & Fermented/unadjusted $\mathrm{pH}$ & $5.5 \pm 0.1$ & $6.6 \pm 0.0$ & $8.4 \pm 0.1$ & $9.3 \pm 0.1$ & $9.5 \pm 0.2$ \\
\hline & Barlow & Unfermented & $5.5 \pm 0.1$ & $6.4 \pm 0.2$ & $8.2 \pm 0.2$ & $9.3 \pm 0.1$ & $9.2 \pm 0.2$ \\
\hline & & Fermented/adjusted $\mathrm{pH}$ & $5.3 \pm 0.2$ & $4.5 \pm 1.6$ & $8.3 \pm 0.1$ & $9.3 \pm 0.1$ & $9.4 \pm 0.2$ \\
\hline & & Fermented/unadjusted $\mathrm{pH}$ & $5.3 \pm 0.1$ & $6.4 \pm 0.1$ & $8.2 \pm 0.2$ & $9.3 \pm 0.1$ & $9.3 \pm 0.2$ \\
\hline
\end{tabular}

${ }^{a}$ Mean value \pm standard error. ${ }^{\mathrm{b}}$ Prebiotic assay time point. 
No statistically significant differences in growth were observed between the sample extracts and prebiotic assay control (water), and between sample extract $\times$ fermentation time point interactions. However, at the $0 \mathrm{~h}$ assay time point, $24 \mathrm{~h}$-fermented wheat extracts had significantly higher $\log \mathrm{CFU} / \mathrm{mL}$ when compared to the $0 \mathrm{~h}$-fermented wheat extracts and were statistically at par with the $48 \mathrm{~h}$ - and $72 \mathrm{~h}$-fermented extracts $(p<0.05)$. These results indicate that the fermented wheat extracts had no negative effect on the growth of $B$. longum and can function as suitable substrates to support the growth of B. longum. Therefore, the LAB-based fermentation of wheat can be advanced as a safe dietary strategy to target and potentially manage pathogenic bacteria such as H. pylori and associated infections, without having any harmful side effects on beneficial gut microbes.

\section{Conclusions}

Fermentation with LAB is an effective and safe bioprocessing strategy to improve the phenolic bioactive-linked functional properties of wheat, hence concurrently enhancing and advancing its role as a functional food or food ingredient for human-health-targeted benefits. Due to the acidic conditions generated during the growth of $\mathrm{LAB}$ and through potential microbial enzymatic action, the fermentation of wheat with LAB can alter its phenolic profile and content, as well as related bioactivity, such as its antioxidant, antihyperglycemic and antimicrobial activity against bacterial pathogens. An acidic $\mathrm{pH}$ can affect the stability of phenolic compounds present in plant-based food substrates such as wheat, as different phenolic bioactive compounds have different sensitivities to low $\mathrm{pH}$, and the acidic conditions generated during fermentation can release bound or esterified phenolics, which in turn enhance phenolic-linked bioactivity. In this study, the improvement in benzoic acid content and enhanced antioxidant activity (DPPH-based) were observed in fermented wheat extracts, while soluble phenolic content remained at a constant level even at the $72 \mathrm{~h}$ fermentation timepoint. Higher antihyperglycemic function-relevant $\alpha$-amylase and $\alpha$-glucosidase enzyme inhibitory activities were also observed in fermented wheat extracts due to the effect of acidic condition generated during LAB growth. Additionally, a combination of low $\mathrm{pH}$, weak organic acid production, and the antimicrobial activity of phenolic compounds during wheat fermentation resulted in the inhibition of the gastriculcer-causing bacterium $H$. pylori, which indicates the potential human gut health benefits of fermented wheat. Furthermore, ancient and modern wheat varieties can serve as a suitable substrate source for the growth of probiotic and beneficial LAB, which can be utilized in designing functional foods and food ingredients. In conclusion, the results of this study provide important insights on the benefits of a LAB-based fermentation strategy, which can be advanced as an effective bioprocessing tool to improve the health-protective functional benefits of underutilized (Emmer) and conventional (Barlow) wheat for wider health-targeted food applications.

Author Contributions: Conceptualization, A.C., D.S. and K.S.; methodology, A.C. and D.S.; validation, and formal analysis, A.C. and D.S.; investigation, A.C. and D.S; resources, K.S.; data curation, A.C. and D.S.; writing - original draft preparation, A.C. and D.S.; writing—review and editing, K.S., D.S. and A.C.; supervision, K.S. and D.S. All authors have read and agreed to the published version of the manuscript.

Funding: This research received no external funding.

Institutional Review Board Statement: Not applicable.

Informed Consent Statement: Not applicable.

Data Availability Statement: The data presented in this study are available on request from the corresponding author.

Acknowledgments: The authors would like to thank Lowell Kaul of Organic Kaul Farms (Harvey, ND, USA) for providing the Emmer wheat and the Department of Plant Sciences, Wheat Variety Breeding Program, North Dakota State University (Fargo, ND, USA) for providing the Barlow wheat.

Conflicts of Interest: The authors declare no conflict of interest. 


\section{References}

1. Skrajda-Brdak, M.; Konopka, I.; Tańska, M.; Czaplicki, S. Changes in the content of free phenolic acids and antioxidative capacity of wholemeal bread in relation to cereal species and fermentation type. Eur. Food Res. Technol. 2019, 245, 2247-2256. [CrossRef]

2. Zhou, Y.; Wang, R.; Zhang, Y.; Yang, Y.; Sun, X.; Zhang, Q.; Yang, N. Biotransformation of phenolics and metabolites and the change in antioxidant activity in kiwifruit induced by Lactobacillus plantarum fermentation. J. Sci. Food Agric. 2020, 100, 3283-3290. [CrossRef] [PubMed]

3. Rakhmanova, A.; Khan, Z.A.; Shah, K. A mini review fermentation and preservation: Role of Lactic Acid Bacteria. MOJ Food Process. Technol. 2018, 6, 414-417. [CrossRef]

4. Gobbetti, M. The sourdough microflora: Interactions of lactic acid bacteria and yeasts. Trends Food Sci. Technol. 1998, 9, 267-274. [CrossRef]

5. Charalampopoulos, D.; Pandiella, S.S.; Webb, C. Growth studies of potentially probiotic lactic acid bacteria in cereal-based substrates. J. Appl. Microbiol. 2002, 92, 851-859. [CrossRef]

6. Paramithiotis, S.; Chouliaras, Y.; Tsakalidou, E.; Kalantzopoulos, G. Application of selected starter cultures for the production of wheat sourdough bread using a traditional three-stage procedure. Process. Biochem. 2005, 40, 2813-2819. [CrossRef]

7. Paramithiotis, S.; Gioulatos, S.; Tsakalidou, E.; Kalantzopoulos, G. Interactions between Saccharomyces cerevisiae and lactic acid bacteria in sourdough. Process. Biochem. 2006, 41, 2429-2433. [CrossRef]

8. Plessas, S.; Alexopoulos, A.; Mantzourani, I.; Koutinas, A.; Voidarou, C.; Stavropoulou, E.; Bezirtzoglou, E. Application of novel starter cultures for sourdough bread production. Anaerobe 2011, 17, 486-489. [CrossRef]

9. Robert, H.; Gabriel, V.; Lefebvre, D.; Rabier, P.; Vayssier, Y.; Fontagné-Faucher, C. Study of the behaviour of Lactobacillus plantarum and Leuconostoc starters during a complete wheat sourdough breadmaking process. LWT-Food Sci. Technol. 2006, 39, $256-265$. [CrossRef]

10. Arendt, E.K.; Ryan, L.A.; Bello, F.D. Impact of sourdough on the texture of bread. Food Microbiol. 2007, 24, 165-174. [CrossRef] [PubMed]

11. Clarke, C.I.; Schober, T.J.; Dockery, P.; O'Sullivan, K.; Arendt, E.K. Wheat Sourdough Fermentation: Effects of Time and Acidification on Fundamental Rheological Properties. Cereal Chem. J. 2004, 81, 409-417. [CrossRef]

12. Corsetti, A.; Gobbetti, M.; De Marco, B.; Balestrieri, F.; Paoletti, F.; Russi, L.; Rossi, J. Combined Effect of Sourdough Lactic Acid Bacteria and Additives on Bread Firmness and Staling. J. Agric. Food Chem. 2000, 48, 3044-3051. [CrossRef]

13. Bello, F.D.; Clarke, C.; Ryan, L.; Ulmer, H.; Schober, T.; Ström, K.; Sjögren, J.; van Sinderen, D.; Schnürer, J.; Arendt, E. Improvement of the quality and shelf life of wheat bread by fermentation with the antifungal strain Lactobacillus plantarum FST 1.7. J. Cereal Sci. 2007, 45, 309-318. [CrossRef]

14. Gül, H.; Özçelik, S.; Sağdıç, O.; Certel, M. Sourdough bread production with lactobacilli and S. cerevisiae isolated from sourdoughs. Process. Biochem. 2005, 40, 691-697. [CrossRef]

15. Leenhardt, F.; Levrat-Verny, M.-A.; Chanliaud, E.; Rémésy, C. Moderate Decrease of pH by Sourdough Fermentation Is Sufficient to Reduce Phytate Content of Whole Wheat Flour through Endogenous Phytase Activity. J. Agric. Food Chem. 2005, 53, 98-102. [CrossRef]

16. Palacios, M.C.; Haros, M.; Sanz, Y.; Rosell, C.M. Phytate degradation by Bifidobacterium on whole wheat fermentation. Eur. Food Res. Technol. 2008, 226, 825-831. [CrossRef]

17. Thiele, C.; Gänzle, M.; Vogel, R.F. Contribution of Sourdough Lactobacilli, Yeast, and Cereal Enzymes to the Generation of Amino Acids in Dough Relevant for Bread Flavor. Cereal Chem. J. 2002, 79, 45-51. [CrossRef]

18. Cakmak, I.; Torun, A.; Millet, E.; Feldman, M.; Fahima, T.; Korol, A.; Nevo, E.; Braun, H.; Özkan, H. Triticum dicoccoides: An important genetic resource for increasing zinc and iron concentration in modern cultivated wheat. Soil. Sci. Plant. Nutr. 2004, 50, 1047-1054. [CrossRef]

19. Chatzav, M.; Peleg, Z.; Ozturk, L.; Yazici, A.; Fahima, T.; Cakmak, I.; Saranga, Y. Genetic diversity for grain nutrients in wild emmer wheat: Potential for wheat improvement. Ann. Bot. 2010, 105, 1211-1220. [CrossRef]

20. Chen, L.; Ren, J.; Shi, H.; Chen, X.; Zhang, M.; Pan, Y.; Fan, J.; Nevo, E.; Sun, D.; Fu, J.; et al. Physiological and Molecular Responses to Salt Stress in Wild Emmer and Cultivated Wheat. Plant. Mol. Biol. Rep. 2013, 31, 1212-1219. [CrossRef]

21. Christopher, A.; Sarkar, D.; Zwinger, S.; Shetty, K. Ethnic food perspective of North Dakota Common Emmer Wheat and relevance for health benefits targeting type 2 diabetes. J. Ethn. Foods 2018, 5, 66-74. [CrossRef]

22. Nevo, E. Evolution of wild emmer wheat and crop improvement. J. Syst. Evol. 2014, 52, 673-696. [CrossRef]

23. Peleg, Z.; Saranga, Y.; Yazici, A.; Fahima, T.; Ozturk, L.; Cakmak, I. Grain zinc, iron and protein concentrations and zinc-efficiency in wild emmer wheat under contrasting irrigation regimes. Plant. Soil 2008, 306, 57-67. [CrossRef]

24. Stallknecht, G.F.; Gilbertson, K.M.; Ranney, J.E. Alternative wheat cereals as food grains: Einkorn, Emmer, Spelt, Kamut, and Triticale. Prog. New Crop. 1996, 156-170.

25. Serpen, A.; Gökmen, V.; Karagöz, A.; Koksel, H. Phytochemical Quantification and Total Antioxidant Capacities of Emmer (Triticum dicoccon Schrank) and Einkorn (Triticum monococcum L.) Wheat Landraces. J. Agric. Food Chem. 2008, 56, 7285-7292. [CrossRef]

26. Zaharieva, M.; Ayana, N.G.; Al Hakimi, A.; Misra, S.C.; Monneveux, P. Cultivated emmer wheat (Triticum dicoccon Schrank), an old crop with promising future: A review. Genet. Resour. Crop. Evol. 2010, 57, 937-962. [CrossRef]

27. Coda, R.; Rizzello, C.G.; Trani, A.; Gobbetti, M. Manufacture and characterization of functional emmer beverages fermented by selected lactic acid bacteria. Food Microbiol. 2011, 28, 526-536. [CrossRef] [PubMed] 
28. Ranilla, L.G.; Christopher, A.; Sarkar, D.; Shetty, K.; Chirinos, R.; Campos, D. Phenolic Composition and Evaluation of the Antimicrobial Activity of Free and Bound Phenolic Fractions from a Peruvian Purple Corn (Zea mays L.) Accession. J. Food Sci. 2017, 82, 2968-2976. [CrossRef]

29. Ankolekar, C.; Pinto, M.D.S.; Greene, D.; Shetty, K. In vitro bioassay based screening of antihyperglycemia and antihypertensive activities of Lactobacillus acidophilus fermented pear juice. Innov. Food Sci. Emerg. Technol. 2012, 13, 221-230. [CrossRef]

30. Shetty, K.; Curtis, O.F.; Levin, R.E.; Witkowsky, R.; Ang, W. Prevention of Vitrification Aßociated with in vitro Shoot Culture of Oregano. (Origanum vulgare) by Pseudomonas spp. J. Plant. Physiol. 1995, 147, 447-451. [CrossRef]

31. Kwon, Y.I.; Vattem, D.A.; Shetty, K. Evaluation of clonal herbs of Lamiaceae species for management of diabetes and hypertension. Asia Pac. J. Clin. Nutr. 2006, 15, 107-118.

32. Re, R.; Pellegrini, N.; Proteggente, A.; Pannala, A.; Yang, M.; Rice-Evans, C. Antioxidant activity applying an improved ABTS radical cation decolorization assay. Free Radic. Biol. Med. 1999, 26, 1231-1237. [CrossRef]

33. Friedman, M.; Jürgens, H.S. Effect of $\mathrm{pH}$ on the Stability of Plant Phenolic Compounds. J. Agric. Food Chem. 2000, 48, 2101-2110. [CrossRef] [PubMed]

34. Brandolini, A.; Castoldi, P.; Plizzari, L.; Hidalgo, A. Phenolic acids composition, total polyphenols content and antioxidant activity of Triticum monococcum, Triticum turgidum and Triticum aestivum: A two-years evaluation. J. Cereal Sci. 2013, 58, 123-131. [CrossRef]

35. Heimler, D.; Vignolini, P.; Isolani, L.; Arfaioli, P.; Ghiselli, L.; Romani, A. Polyphenol Content of Modern and Old Varieties of Triticum aestivum L. and T. durum Desf. Grains in Two Years of Production. J. Agric. Food Chem. 2010, 58, 7329-7334. [CrossRef]

36. Reddivari, L.; Hale, A.L.; Miller, J.C., Jr. Genotype, Location, and Year Influence Antioxidant Activity, Carotenoid Content, Phenolic Content, and Composition in Specialty Potatoes. J. Agric. Food Chem. 2007, 55, 8073-8079. [CrossRef]

37. Liyana-Pathirana, C.M.; Shahidi, F. Antioxidant Activity of Commercial Soft and Hard Wheat (Triticum aestivum L.) as Affected by Gastric pH Conditions. J. Agric. Food Chem. 2005, 53, 2433-2440. [CrossRef]

38. Ripari, V.; Bai, Y.; Gänzle, M.G. Metabolism of phenolic acids in whole wheat and rye malt sourdoughs. Food Microbiol. 2019, 77, 43-51. [CrossRef]

39. Sánchez-Maldonado, A.; Schieber, A.; Gänzle, M. Structure-function relationships of the antibacterial activity of phenolic acids and their metabolism by lactic acid bacteria. J. Appl. Microbiol. 2011, 111, 1176-1184. [CrossRef]

40. Antognoni, F.; Mandrioli, R.; Potente, G.; Saa, D.L.T.; Gianotti, A. Changes in carotenoids, phenolic acids and antioxidant capacity in bread wheat doughs fermented with different lactic acid bacteria strains. Food Chem. 2019, 292, 211-216. [CrossRef]

41. Arora, S.; Jood, S.; Khetarpaul, N. Effect of germination and probiotic fermentation on nutrient composition of barley based food mixtures. Food Chem. 2010, 119, 779-784. [CrossRef]

42. Adebo, O.A.; Medina-Meza, I.G. Impact of Fermentation on the Phenolic Compounds and Antioxidant Activity of Whole Cereal Grains: A Mini Review. Mol. 2020, 25, 927. [CrossRef] [PubMed]

43. Cotter, P.D.; Hill, C. Surviving the Acid Test: Responses of Gram-Positive Bacteria to Low pH. Microbiol. Mol. Biol. Rev. 2003, 67, 429-453. [CrossRef] [PubMed]

44. Rosenquist, H.; Hansen, $\AA$. The antimicrobial effect of organic acids, sour dough and nisin against Bacillus subtilis and B. licheniformis isolated from wheat bread. J. Appl. Microbiol. 1998, 85, 621-631. [CrossRef]

45. Cleveland, J.; Montville, T.J.; Nes, I.F.; Chikindas, M.L. Bacteriocins: Safe, natural antimicrobials for food preservation. Int. J. Food Microbiol. 2001, 71, 1-20. [CrossRef]

46. Hirshfield, I.N.; Terzulli, S.; O’Byrne, C. Weak Organic Acids: A Panoply of Effects on Bacteria. Sci. Prog. 2003, 86, 245-270. [CrossRef]

47. Bonifácio, B.V.; Ramos, M.A.D.S.; Da Silva, P.B.; Bauab, T.M. Antimicrobial activity of natural products against Helicobacter pylori: A review. Ann. Clin. Microbiol. Antimicrob. 2014, 13, 1-10. [CrossRef]

48. Lin, Y.T.; Kwon, Y.I.; Labbe, R.G.; Shetty, K. Inhibition of Helicobacter pylori and Associated Urease by Oregano and Cranberry Phytochemical Synergies. Appl. Environ. Microbiol. 2005, 71, 8558-8564. [CrossRef]

49. Sarkar, D.; Ankolekar, C.; Pinto, M.; Shetty, K. Dietary functional benefits of Bartlett and Starkrimson pears for potential management of hyperglycemia, hypertension and ulcer bacteria Helicobacter pylori while supporting beneficial probiotic bacterial response. Food Res. Int. 2015, 69, 80-90. [CrossRef]

50. Daglia, M. Polyphenols as antimicrobial agents. Curr. Opin. Biotechnol. 2012, 23, 174-181. [CrossRef]

51. Cowan, M.M. Plant Products as Antimicrobial Agents. Clin. Microbiol. Rev. 1999, 12, 564-582. [CrossRef] [PubMed]

52. Jayaraman, P.; Sakharkar, M.K.; Lim, C.S.; Tang, T.H.; Sakharkar, K.R. Activity and interactions of antibiotic and phytochemical combinations against Pseudomonas aeruginosa in vitro. Int. J. Biol. Sci. 2010, 6, 556-568. [CrossRef] [PubMed]

53. Jayaraman, P.; Sakharkar, K.R.; Sing, L.C.; Chow, V.; Sakharkar, M.K. Insights into antifolate activity of phytochemicals against Pseudomonas aeruginosa. J. Drug Target. 2010, 19, 179-188. [CrossRef] [PubMed]

54. Chibane, L.B.; Degraeve, P.; Ferhout, H.; Bouajila, J.; Oulahal, N. Plant antimicrobial polyphenols as potential natural food preservatives. J. Sci. Food Agric. 2019, 99, 1457-1474. [CrossRef] [PubMed]

55. Radulovic, N.; Blagojevic, P.; Stojanovic-Radic, Z.; Stojanovic, N. Antimicrobial Plant Metabolites: Structural Diversity and Mechanism of Action. Curr. Med. Chem. 2013, 20, 932-952. [CrossRef] [PubMed]

56. Díaz-Gómez, R.; López-Solís, R.; Obreque-Slier, E.; Toledo-Araya, H. Comparative antibacterial effect of gallic acid and catechin against Helicobacter pylori. LWT-Food Sci. Technol. 2013, 54, 331-335. [CrossRef] 